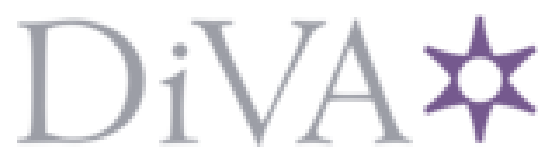

http://www.diva-portal.org

\title{
Preprint
}

This is the submitted version of a paper published in International Finance Review.

Citation for the original published paper (version of record):

Fredrik, J. (2008)

Legal Rights Matter: Evidence from Panel Data on Creditor Protection and Debt.

International Finance Review, 9: 303-336

http://dx.doi.org/10.1016/S1569-3767(08)09013-4

Access to the published version may require subscription.

N.B. When citing this work, cite the original published paper.

Permanent link to this version:

http://urn.kb.se/resolve?urn=urn:nbn:se:su:diva-98056 


\title{
Legal Rights Matter: Evidence from Panel Data on Creditor Protection and Debt
}

\author{
by \\ Thomas W. Hall* \\ and \\ Fredrik Jörgensen** \\ June, 2008
}

\begin{abstract}
Using panel data derived from recent financial statements, we examine the relationship between changing creditor protection and leverage (and debt maturity) in a number of emerging market countries located in Central and Eastern Europe. We examine unlisted firms, which are more likely than listed companies to face credit constraints. Our main hypothesis is whether unlisted firms change their leverage and debt maturity as creditor rights increase. We confirm this to be the case at both the country- and firm-level; our findings are robust to alternative econometric specifications and inclusion of countrylevel and firm-level controls. We also find that legal origin is related to the level of debt and its maturity.
\end{abstract}

JEL Categories: G21; G30; K20

Keywords: Investor Protection, Creditor Rights, Leverage, Debt Maturity, Emerging Markets

*Contact author: Department of Accounting, Economics, and Finance, Joseph W Luter III College of Business and Leadership, Christopher Newport University, One University Place, Newport News VA 23606, tel. 757-594-8916; fax 757-594-7808, thomas.hall@cnu.edu; **BEEGS- Baltic and East European Graduate School, Södertörns Högskola (South Stockholm University College), Phone: +46-8-608 4812, Fax : +46-8-608 4360, Email: fredrik.jorgensen@sh.se 


\section{Legal Rights Matter: Evidence from Panel Data on Creditor Protection and Debt}

\section{Introduction}

In this study, we consider the links between legal protection of creditors and the amount and maturity of debt assumed by unlisted, privately-held firms. ${ }^{1}$ We use tens of thousands of firm-year observations collected from a region that has undergone significant reforms over the past fifteen years. This allows us to analyze how temporal variation in the level of investor protection is related to financial market outcomes. ${ }^{2}$ The countries of Central and Eastern Europe ${ }^{3}$ in fact provide an ideal natural laboratory for examining the relationship between changes in creditor rights and firm-level financing

\footnotetext{
${ }^{1}$ Although equity market development seems to be related to long-run economic performance (Levine, 1998), the equity of most firms in most countries is not listed on public exchanges. The financing constraints of small and medium-sized firms relative to large firms have been studied in other contexts (Beck, et al., 2002, 2004, 2005), and the result is that access to highly liquid public equity markets is the exception rather than the rule for the vast majority of small and medium size firms in most countries. Indeed, given the relatively low level of liquidity, transparency, and viability of many national stock markets, from the perspective of the majority of individual firms around the world, "external" finance essentially boils down to two categories: private equity investment from a small group of relatively wealthy investors or other (often, industrial) firms, or debt investment (either in the form of loans from financial institutions such as banks, or, more rarely, corporate bond markets). These firms are not likely to have owner-manager agency problems that must be considered in studies of publicly traded firms with dispersed shareholders.

${ }^{2}$ Many recent cross-country studies of access to external finance (e.g., Demirguc-Kunt and Maksimovic, 1998, 1999, 2002) omit Central and Eastern Europe for the very reason that the region has undergone such extensive institutional change. We see this reform, however, as a rationale for more in-depth analysis. ${ }^{3}$ Previous studies that have considered external finance and legal development in Central and Eastern Europe (Slavova, 1999; Köke and Schröder, 2003; Pistor, Raiser, and Gelfer, 2000; Krkoska, 2001; Berglöf and Bolton, 2002) tend to do so at the aggregate level, examining stock market development or banking assets as a portion of GDP, but eschewing examination of individual firms. The factors associated with capital structure of individual firms are therefore difficult to determine. The literature on market-based vs. bank-based financial system structure and firm-level access to external finance is generally cross-sectional in nature, and often omits countries from Central and Eastern Europe. This is somewhat ironic given that the seminal research on bank- vs. market-led development contrasted the nature of external finance in Russia, Germany, and the United Kingdom (Gershenkron, 1962).
} 
choices. ${ }^{4}$ Our focus throughout is on the vast number of under-studied firms that are not listed on national stock exchanges, and more likely to face credit constraints.

We find that increased protection of creditors is associated with higher levels of debt and longer debt maturity. We also find that institutional effectiveness (rule of law) and changes in creditor protection appear to be substitutes in achieving more leverage and longer-term debt maturity. These findings are robust to various econometric specifications such as robust ordinary least squares and generalized least squares, as well as to inclusion of controls for macroeconomic (economic growth, money supply changes, $\log$ of per capita output, banking sector reform) and firm-level (the tangibility and specificity ${ }^{5}$ of assets, size measured as log of total assets, return on assets, and effective tax rate) factors.

Giannetti (2003), employing data from the same Amadeus data base that we use, finds that national institutions affect firm-level financing choices. La Porta, et al (1997, 1998, 2006) find a positive relationship between the size of financial markets in different countries and the level of legal protection afforded to investors. A very long-range study of financial sectors in several advanced capitalist countries (Rajan and Zingales, 2003), however, presents evidence that is inconsistent with this perspective. Although we do not settle this debate, ours is the first contribution we know of that uses firm-level panel data

\footnotetext{
${ }^{4}$ One examination that specifically addresses firm-level investment (Johnson, McMillan, and Woodruff, 2002) focuses on manufacturing companies based on a 1997 survey, but is unable to examine legal origin or the effect of changes in de jure regulations over time, and only includes five countries (Poland, Romania, Slovakia, Ukraine, and Russia). An interesting examination of changes in laws on the books (Hyytinen, Kuosa, and Takalo, 2003) specifically examines Finland, so is not comparative in nature; its findings could therefore be less universal than the cross-country, time-series investigation that we employ. ${ }^{5}$ The specificity of assets is important for the firm's decision as to the quantity, and potentially, maturity, of a firm's debt obligations (Acharya, et al 2004). We employ a dummy variable that takes the value of 1 for firms in industry groups that generally possess assets that are difficult to liquidate, with ambiguous effects on leverage (firms with high asset specificity in an equity-friendly environment use more leverage than in a debt-friendly environment; the reverse is true for firms with low asset specificity). Firms with two-digit SIC codes in the following ranges received a "1" for this variable: 10-14 (mining), 20-39 (manufacturing) and 40-49 (transportation).
} 
to address this issue in multiple countries over time. Many studies in the burgeoning law and finance literature employ data at the country level (which can obscure the firm-level links between the financial and real sector) or from publicly traded companies; our study is unique in using disaggregated data from privately-held firms.

Use of firm-level data has the advantage of controlling for unique issues that are specific to the leverage of an individual firm. We choose to examine unlisted companies because publicly traded firms have a relatively high level of access to external finance due to their status on exchanges: they have access to a larger pool of equity and fixed income investors than is the case for the vast majority of privately-held companies, especially in the emerging market context. This study aims to further our understanding of the relationship between creditor protection and the financial decisions of such firms. We focus on companies located in a region that is often excluded in cross-country studies due to the dynamic nature of economic change there; it is this very dynamism that forms the basis for our study.

Our specific hypotheses concern whether (1) changes in creditor protection are related to leverage and debt maturity, either at the country- or firm-level; (2) institutions related to creditor protection legislation (rule of law) are related to leverage and debt maturity; and (3) legal origin is related to firm leverage and debt maturity.

The paper proceeds as follows. We begin by discussing our data encompassing unlisted firms in Central and Eastern Europe. We then consider testable hypotheses concerning firm-level leverage and debt maturity, and generate two empirical models: one for leverage (long-term debt over total assets) and one for debt maturity (long-term debt over total debt). We estimate both models using country-level averages of 
individual firm-level data. Next, we turn to various econometric specifications using firm-level data, which has the advantage of controlling for factors that are specific to individual companies. We conclude by considering the policy relevance of our findings and indicate some directions for future research.

\section{DATA}

We use the Central and Eastern European portion of the Amadeus database, covering most of the major countries in that region. Our study encompasses the years that meet two criteria: a sufficient amount of firm-level data exist, and information on the changing level of creditor rights is available (from Pistor, et al, 2000). We extract data from fourteen nations during the years 1997 - 2001 (prior to 1997, Amadeus data are extremely sparse; after that period, we did not have current creditor rights scores).

Giannetti (2003) uses this data source for an analysis of Western European countries. She discusses the quality of the data and constructs "average" balance sheets for nonlisted firms in those countries, which we do as well. The Central and Eastern Europe portion of the database is described in Klapper, et al, $(2002)^{6}$; the data are also used in empirical tests of leverage adjustment speed by Nivorozhkin (2005). Desai, Gompers, and Lerner (2003) use the data to show that firms in Central and Eastern Europe face capital constraints induced by institutional factors, which affect the ability of firms in transition to grow.

\section{A. Data Quality, Industry Selection, and Truncation}

\footnotetext{
${ }^{6}$ The version of the Amadeus database we use includes firms with operating revenue in excess of $€ 10$ million; total assets above $€ 20$ million, and 100 or more employees, except for Russia and Ukraine where the respective cut-offs are $€ 15$ million, $€ 30$ million, and 150 .
} 
Data on small, nonlisted companies are often difficult to obtain, and due to the lack of investor demand for such information, do not undergo the rigorous analysis and due diligence of, for example, accounting statements associated with publicly listed companies in the United States ${ }^{7}$. There was no equivalent of the Securities and Exchange Commission to enforce accounting quality in our countries during the period examined, and most banks and lenders relied on insider information that might not be revealed to agencies that report the information that ends up in the Amadeus database. This issue confronts examination of nonlisted firms located in many parts of the world, but, in addition, our data come from countries that do not have long-standing traditions of reporting firm-level information to financial markets, or even to lenders (often, the state interfered in project selection or directly provisioned credit). Thus, some issues concerning the data arise, which we need to address.

First, if the data are simply of "bad quality" or not indicative of actual firm performance or conditions, such noise would make the generation of statistically significant findings on our part more difficult. In fact, any issues of data quality mean that the results we derive probably understate actual relationships relative to findings that are generated using "perfect" financial and accounting data for unlisted firms in an emerging market setting, which do not exist in any event. ${ }^{8}$

Another issue relates to the fact that even if the data collection services accurately gather the underlying data, it is still possible that managers of the reporting firms might intentionally distort their firms' financial situation. It is of course unlikely that such

\footnotetext{
${ }^{7}$ Which, of course, are not "perfect" either as recent accounting scandals and current concerns about transparency of securitized assets demonstrate.

${ }^{8}$ To remove clearly nonsensical data points and improve the overall quality of the data set, we only consider observations for which data on all independent variables used in that specification exist; we also use a truncation procedure (described below).
} 
managers are intentionally reporting information designed to confound studies on capital structure, whatever their motives for reporting misleading statements might be, if any. In general, misreporting of financial results is often designed to understate income in order to avoid taxation; our data, however do not come from tax authorities but from chambers of commerce and similar such agencies that collect the data that ends up in the Amadeus data base. Any motives of firms to present misleading accounting data in this context are unclear.

In addition, unlike the case of the United States, interest payments on debt are not uniformly treated as tax deductions for firms in the region (PricewaterhouseCoopers, 2001a, 2001b), and even if they were, this fact would affect the income statement more than the balance sheet, which is more germane for leverage analysis. To ensure underreporting of income is not affecting our results, we conduct two sets of tests, those using income statement variables, and those omitting them. In addition, recall that, in the absence of robust equity markets, and certainly in the case of most privately-held companies, there is little motivation for managers to misreport information, since they are not trying to entice investors to purchase stock in their firms.

Issues relating to how results are affected by data quality are compounded by the fact that we might reasonably expect the coefficient of the creditor rights variables to be very small, due to a number of factors. Firms might not modify their lending behavior immediately following changes in creditor protection—or at all—for a number of reasons. First, they might be able to grow at a sufficient rate from retained earnings; they might not seek additional debt financing in the time period we are considering irrespective of any changes in creditor rights. It is also difficult to measure the magnitude 
of creditor rights improvement (although we make some efforts in this direction), so a minor improvement in creditor rights might not indicate a large increase in the assumption of debt. Even if they "should" increase their leverage according to some objective measure, they might neither recognize nor act upon their new ideal ${ }^{9}$ capital structure. During times of macroeconomic and institutional uncertainty, lending might not increase even in the new environment of higher legal protections for creditors.

We employ a number of strategies to provide confidence in our findings, despite these potential limitations on the quality of our data. First, we employ both national averages of accounting data (in which case we are unable to use firm-level controls), as well as company-level analyses using large amounts of firm-years. Each type of test provides a check on the other, and the large sample size smoothes the impact of any outliers. Second, we only use observations where all data points are present for the given year, inherently selecting for firms with more complete and, presumably, higher-quality data. Third, we present a number of econometric specifications for each model, increasing our confidence in the robustness of our results.

In order to be consistent with previous studies on capital structure in other settings, we rely on techniques and data selection methods used by other researchers. Initially, as is generally the practice in empirical studies of leverage, we eliminate all firms with no reported SIC code and all firms with SIC codes beginning with a 6 - the latter category includes financial firms such as depository institutions that have unique

\footnotetext{
${ }^{9}$ Fidrmuc and Fidrmuc (2007) find that institutional factors such as lack of skilled management in Central and Eastern Europe can put constraints on value-maximizing behavior, even in closely-held firms with few agency problems. For an examination of how quickly firms in Central and Eastern Europe recognize and achieve their ideal capital structure, see Nivorozhkin, 2005. Flannery and Rangan (2006) find that even in advanced industrialized countries, the typical firm only closes about one-third of the gap between its actual and target debt ratios each year.
} 
capital structures with typically high relative levels of liabilities (often, deposits) and very little owners' equity. ${ }^{10}$

Our dependent and choice accounting variables are based on those of Rajan and Zingales, 1995; Giannetti, 2003; and Demigurc-Kunt and Maksimovic, 1999. Our industry selection is based on that of Fan, Titman, and Twite (2003), who study capital structure in a number of emerging market countries, but do not consider changes in creditor rights over time. Our non-accounting independent variables such as creditor protection and banking sector reform come from previous country-level studies (Pistor, Raiser, and Gelfer, 2000; EBRD, 2000).

We use a creditor rights measure that has the advantage of being designed specifically for "emerging" capital markets. ${ }^{11}$ It is more applicable to our countries than the typical creditor rights variable (CRED, in La Porta, et al, 1997 and 1998) used in the literature because we include both legal remedy in the case of bankruptcy, as well as the effectiveness of collateral laws. In countries with no collateral registry, perfection of a claim is more difficult, which in turn could retard the provision of credit. In addition, our measure (EmCred) excludes a distinction that is appropriate for some advanced capitalist economies but is less important for debt contracts elsewhere: the existence of creditor

\footnotetext{
${ }^{10}$ Meaning, we exclude financial services firms, which have very different leverage characteristics than typical companies that manufacture goods or provide non-financial services. Note that Amadeus information is primarily in the form of unconsolidated financial statements. Although it might seem preferable to use consolidated statements, they are available for only a very small portion of firms contained in the database. In any event, studies of spin-offs (Dittmar, 2004; Mehrotra, et al, 2003) indicate that firms allocate leverage to their spin-offs based on attributes important at the consolidated firm level. Thus, asset tangibility of a spin-off is positively related to its leverage. The same is true (higher leverage) for spin-off firms with assets that have lower liquidation costs. Differences in leverage, however, are positively related to differences in profitability. Neverthless, as will be explored in more detail below, in most specifications we found ROA was negatively related to leverage and debt maturity, leading us to believe that our unconsolidated statements are not grossly distorting relationships that hold for publiclytraded firms for which consolidated statements exist.

${ }^{11}$ Three measures (credit con, collateral, and remedy) are used to construct the EmCred emerging markets equivalent of the LLSV CRED variable, as described in the text. See Pistor, et al (2000), and Panel C in the Appendix.
} 
consent before determining liquidation as opposed to reorganization forms part of the LLSV CRED score, but none of the countries in Central and Eastern Europe during the time period we consider had a clear, US-style distinction between these two types of bankruptcy. $^{12}$

Selection of industries in leverage studies is very important. One potential drawback of using country-level data is that national variation in the prevalence of different industries might distort the level of average company leverage, irrespective of country-level institutional factors. Fan, Titman, and Twite (2003), in fact, found that country was more important than industry group in explaining firm-level capital structure among listed firms all over the world. To be consistent with their study, to control for the fact that certain industries are more prevalent in some countries than others, and for the practical reason of reasonably limiting the sheer quantity of data that confront analyses of the Amadeus data set, we restrict our firm-years according to the SIC code selection of that paper. As in that study, we include only firms that are likely to have enough tangible assets and revenue stability to be likely to borrow in any country setting (we didn't want to include firms that possess little debt under any circumstances; we are interested in how firms that are likely to borrow would be affected by changes in creditor protection). These are the companies that are most likely to take advantage of increased creditor protection by actually borrowing more under improved conditions. Specifically, we examine companies with codes as follows: business services (SIC 73), chemicals (SIC 28), construction (SIC 15, 16, 17), food and beverage (SIC 20), communication (SIC 48), metal fabrication (SIC 33, 34), resources (SIC 10, 12), newspapers (SIC 27), paper and

\footnotetext{
${ }^{12}$ The DeltaEmCred variable takes values of " 1 " if there was an improvement in creditor rights (EmCred) between 1996 and 1998.
} 
pulp (SIC 26), wholesale (SIC 50, 51), and retail (SIC 52-59). Based on this procedure that eliminates services and other firms that are unlikely to respond to any changes in creditor protection, the number of leverage (long-term debt over total assets) observations declined by 77,210 to a new total of 54,754; maturity (long-term debt over total debt) observations declined by 77,068 to 54,622 .

Large datasets containing thousands of firm-year observations always include certain data points that are clearly spurious. A literature review of research on capital structure (Frank and Goyal, 2005) specifies two typical approaches for dealing with such situations: truncation and winsorization. Truncation refers to omitting observations with "strange" or nonsensical values. Winsorization refers to replacing values above, for example, the $99^{\text {th }}$ percentile with the value of the $99^{\text {th }}$ percentile. Given the large number of firms with total debt greater than total assets (about five percent of firm-year observations had a debt/asset ratio greater than one ${ }^{13}$ ), for the empirical tests that follow, we truncated all observations with total debt to total assets greater than $0.99 .{ }^{14}$ The truncation procedure amounted to a decline from 54,754 to 49,846 leverage observations and a decline from 54,622 to 49,702 maturity observations. Note that we only include observations that had data on all variables contained in that estimation; conversely, it is not necessary that data be available for all years in the sample period of $1997-2001$ for a firm-year to be included in a given specification.

\section{B. Data Description}

\footnotetext{
${ }^{13}$ For maximum values by country, see Panels A and B of Table 2.

${ }^{14} \mathrm{We}$ ran other estimations without truncation with similar results. Note that it is not impossible for firms to have negative book equity (Welch, 2004). Nevertheless, given the fact that our firms are unlisted, market values for either debt or equity are unavailable to us.
} 
Using the West European portion of the Amadeus data, Giannetti (2003) constructed an "average" balance sheet for firms in different countries, expressing all items as a portion of total assets. She reported that long-term debt ranges from $1.56 \%$ (Italy) to $15.96 \%$ (Ireland); fixed assets range from $30.38 \%$ (France) to $72.01 \%$

(Netherlands). Figure 1 represents a simplified, unweighted average balance sheet based on our data from privately-held firms in Central and Eastern Europe. On average, our companies had less than 5\% of their assets funded by long-term debt; fixed assets were around $46 \%$ of total assets. Our firms had less long-term debt than in any Western European country except Italy, on average.

\section{INSERT FIGURE 1 ABOUT HERE}

Table 1 presents descriptive statistics for our study. Panels A and B present data on the two dependent variables we use: leverage (long-term debt divided by total assets or LTD/TA) and maturity (long-term debt divided by total debt or LTD/TD). In most ${ }^{15}$ of the countries, the quantity of debt is quite reasonable and seems appropriate. The highest average leverage was in Latvia (12.59\%); Lithuania had the longest average debt maturity $(22.83 \%)$. Hungary had very low levels of both leverage $(0.83 \%)$ and debt maturity (1.38\%). Very few firms reported using solely long-term debt (with maximum values of $100 \%$ for LTD/TD), but the maximum generally seems very reasonable in the range of $80-90 \%$.

\footnotetext{
${ }^{15}$ Note that no firms located in Croatia or Slovenia had long-term debt, so the maximum values for LTD/TA and LTD/TD are zero. We did not exclude firms from these countries from our analysis, however, because the number of observations is small, and it seemed arbitrary to simply discard them. Results for all of our estimations excluding these countries are available from the authors by request, and the findings are very consistent with those reported in the paper.
} 


\section{INSERT TABLE 1 ABOUT HERE}

Panels C and D of Table 1 present summaries of the dependent variables used in our analysis, broken down by country and year. In general, we have more observations from firms in the later years - for example, the Russian Federation had no observations in 1997, but had over 3,000 in 2001. Perhaps surprisingly, there is no obvious trend towards increasing leverage or debt maturity in the five years we study, with average annual levels of long term debt fluctuating around 5\% relative to assets and $9 \%$ relative to total debt.

Panel E of Table 1 contains information on some of the country-level variables we use. Rule of Law and EmCred (the level of creditor protection for emerging market countries) are based on indices contained in Pistor, et al (2000). For econometric reasons explained in more detail below, we develop a dummy variable using the EmCred index score: DeltaEmCred takes the value of " 1 " for any firm-year observations that followed an improvement in creditor rights. About a quarter $(25.53 \%)$ of the observations in the overall dataset were associated with improved creditor rights. The average values for all firms of Rule of Law and EmCred were 5.8 and 7.2. The Appendix contains more information on our variables, their construction, and sources.

\section{COUNTRY-LEVEL ANALYSIS}

A previous study (Pistor, et al, 2000) examined changing creditor rights in Central and Eastern Europe using standard country-level data on market capitalization as a 
portion of GDP and private credit over GDP. Public equity markets in these countries, however, include only a very small number of (relatively quite large) firms. ${ }^{16}$ Any increase in private credit over GDP might indeed reflect a larger number of firms receiving more loans; it might also be related to more borrowing at a small number of large, publicly-traded companies. To be consistent with the previous study of changing creditor rights (Pistor, et al, 2000), we begin our analysis by using country-level average values of firm-level variables. In a subsequent section, we turn to company-specific data using controls at the level of the firm.

\section{INSERT TABLE 2 ABOUT HERE}

The country-level data used in these tests is presented in Table 2, which contains information on controls such as per capita output, liquidity, and GDP growth. For our analysis of debt maturity, we include an additional control, the term spread, which contains information on the yield curve (difference between short-term borrowing rate and long-term lending rate) for each year in each country. We now turn to our countrylevel models and econometric methods.

\section{A. Country-Level Models}

\footnotetext{
${ }^{16}$ Pistor, et al (2000) include an additional "corrected" measure of stock market capitalization, derived by multiplying the value by the share of firms with 3 or more outside owners, based on survey data. This was meant to incorporate the effect of dispersed ownership, an important issue in publicly listed firms. Since all of our firms are closely held, corporate governance issues (lack of incentive alignment between managers and owners) was not a major concern in our data set. A companion paper (Hall and Joergenson, 2008) examines ownership issues throughout Europe, based on the Amadeus data.
} 
We begin our statistical analysis by estimating the following model, with dependent variable average value of long-term debt over total assets:

$$
\begin{aligned}
& \left(\mathrm{LTD}_{\mathrm{TA}}\right)_{\mathrm{i}, \mathrm{t}}=\alpha+\beta 1 \mathrm{EffTax}_{\mathrm{i}, \mathrm{t}}+\beta 2 \mathrm{LnPCgdp}_{\mathrm{i}, \mathrm{t}}+\beta 3 \mathrm{M} 3 / \mathrm{GDP}_{\mathrm{i}, \mathrm{t}}+\beta 4 \mathrm{GDPgrowth}_{\mathrm{i}, \mathrm{t}}+ \\
& \beta 5 \text { DeltaEmCred }_{\mathrm{i}, \mathrm{t}}+\beta 6 \text { RuleLaw }_{\mathrm{i}}+\varepsilon
\end{aligned}
$$

where subscripts indicate that variables are indexed on country i during year t. Our choice variable DeltaEmCred is a dummy variable taking the value of " 1 " for any observations in which creditor rights improved in the prior period. ${ }^{17}$ The natural log of per capita output (LnPCgdp, calculated at purchasing power parity) measures the overall level of economic development of the country, which is presumably related to the sophistication of legal institutions, financial market depth, and the ability of firms to obtain leverage (and, longer maturity debt). ${ }^{18}$ We also include a measure of the money supply relative to output (M3/GDP), which incorporates any inflationary results of monetary policy that could affect the level of credit in the economy. Finally, we control for GDP growth to account for cyclical economic expansions that are presumably associated with the quantity of commercial lending. The level of legal and institutional development clearly affects credit markets, even beyond what could be captured by log of per capita output. In fact, using aggregate data, Pistor, et al (2000) argue that legal

\footnotetext{
${ }^{17}$ Thus, for a 1999 financial statement, the variable DeltaEmCred takes the value of " 1 " if the 1998 creditor rights score is higher than it was in 1996. If creditor rights did not improve, the variable takes a value of "0". As revealed in Panel D of the Appendix, creditor rights improved between 1996 and 1998 for five countries: Latvia, Lithuania, Poland, the Russian Federation, and the Slovak Republic. Below, we consider a finer measure (EmCred) of the magnitude of creditor rights in a firm-level fixed-effects setting.

${ }^{18}$ This is an important control especially for the legal origin variables, since per capita output is regionally heterogenous, with richer countries located in the north and west (with German legal heritage), and poorer countries in the south and east (with French and Eurasian legal heritage, respectively).
} 
effectiveness (enforcement) is more important than stipulated legal rules in determining capital market characteristics. Therefore, in our estimations we include a measure for enforcement: the rule of law (RuleLaw).

In our second model, we consider debt maturity using as our dependent variable long-term debt over total debt:

$$
\begin{aligned}
& \left(\text { LTD }_{\text {TD }}\right)_{\mathrm{i}, \mathrm{t}}=\alpha+\beta 1 \text { EffTax }_{\mathrm{i}, \mathrm{t}}+\beta 2 \operatorname{LnPCgdp}_{\mathrm{i}, \mathrm{t}}+\beta 3 \mathrm{M} 3 / \mathrm{GDP}_{\mathrm{i}, \mathrm{t}}+\beta 4 \text { GDPgrowth }_{\mathrm{i}, \mathrm{t}}+ \\
& \beta 5 \text { DeltaEmCred }_{\mathrm{i}, \mathrm{t}}+\beta 6 \text { RuleLaw }_{\mathrm{i}}+\beta 7 \text { TermSpread }_{i, \mathrm{t}}+\varepsilon
\end{aligned}
$$

with indexation and variables described as above. For the estimations of model (2), we employ an additional control TermSpread that is simply the difference between lending (long-run) and deposit (short-run) interest rates as reported in the World Development Indicators database. ${ }^{19}$ Definitions and sources of all variables are reported in the Appendix.

\section{B. Country-Level Econometric Specifications and Findings}

To demonstrate the robustness of our findings, we employ several alternative estimation techniques. We begin with ordinary least squares estimation, which is consistent with previous studies of leverage (Fan, et al, 2003). The second model employs robust OLS, which uses White's correction of error terms for heteroskedasticity that can affect results derived from using multiple observations from the same country.

\footnotetext{
${ }^{19}$ The World Development Indicators did not include such data for Romania, so firms in that country are unfortunately omitted from our debt maturity specifications.
} 
Given that our dependent variable is truncated to lower values of 0 and upper values of 1 , we also use Tobit estimation. Finally, we estimate a generalized least squares (with country-level fixed effects) model which is appropriate for the panel nature of the data set. We employ each of these estimation methods twice, first using leverage (total debt over total assets) and then debt maturity (long term debt over total debt) as the dependent variables, as per models (1) and (2).

\section{INSERT TABLE 3 ABOUT HERE}

The results of the analysis are presented in Table 3, the first four columns of which use leverage (long-term debt over total assets) as the dependent variable. In all of the specifications with a good fit (those with F-statistic $p$-values significantly different from zero), the coefficient for the choice variable DeltaEmCred is positive at better than the $5 \%$ level, although not large in magnitude. Only in the generalized least squares estimation is the coefficient for this variable not significant. Perhaps due to the small sample size (40), the (country-level) fixed-effects model had relatively poor fit (with Fstatistic of only 0.47 ). Below, we will consider firm-level fixed effects on a much larger data set that is available when we use disaggregated individual company financial statements.

In terms of the maturity estimations (those using long-term debt over total debt as the dependent variable), we have broadly similar results. In all specifications, we see a consistent, positive coefficient for the DeltaEmCred variable with a high level of 
significance. The findings indicate that firms operating in an environment of improved creditor rights have, on average, $7.3 \%$ more long-term debt as a portion of total debt.

\section{FIRM-LEVEL ANALYSIS: LEVERAGE AND MATURITY}

Our country-level findings are indicative of a relationship between changes in creditor protection and firm-level financing choices. Analyses using country-level data, however, might obscure important firm-level financing choices-if the composition of firms within a country is not consistent over time, changes in average firms might not indicate changes in the behavior of individual firms. The highly dynamic environment of Central and Eastern Europe during the late 1990s and early 2000s makes this issue particularly salient. Thus, a major advantage of using firm-level data is the ability to control for unique factors that have been found to affect leverage (Rajan and Zingales, 1995). Our additional controls include size, return on assets, and tangibility of assets. In the transition setting with less developed credit institutions relating to the perfectibility of collateral, we include an additional variable, asset specificity, which relates to the ability of physical assets to serve as collateral.

\section{A. Firm-Level Leverage Model}

To examine leverage of unlisted companies in Central and Eastern Europe, we estimate the following model: 


$$
\begin{aligned}
& (\mathrm{LTD} / \mathrm{TA})_{\mathrm{j}, \mathrm{i}, \mathrm{t}}=\alpha+\beta 1 \operatorname{EffTax}_{\mathrm{j}, \mathrm{i}, \mathrm{t}}+\beta 2 \operatorname{Tang}_{\mathrm{j}, \mathrm{i}, \mathrm{t}}+\beta 3 \mathrm{ROA}_{\mathrm{j}, \mathrm{i}, \mathrm{t}}+\beta 4 \mathrm{LNTA}_{\mathrm{j}, \mathrm{i}, \mathrm{t}}+ \\
& \beta 5 \text { AssetSpec }_{\mathrm{j}, \mathrm{i}, \mathrm{t}}+\beta 6 \operatorname{LnPCgdp}_{\mathrm{i}, \mathrm{t}}+\beta 7 \mathrm{M} 3 / \mathrm{GDP}_{\mathrm{i}, \mathrm{t}}+\beta 8 \mathrm{GDPgrowth}_{\mathrm{i}, \mathrm{t}}+9 \mathrm{RuleLaw}_{\mathrm{i}}+ \\
& \beta 10 \text { DeltaEmCred }_{\mathrm{i}, \mathrm{t}-1}+\varepsilon
\end{aligned}
$$

where variables are indexed on firm $j$ in country $i$ during year $t$.

The controls include firm-level and country-level variables. As in previous empirical leverage studies (Rajan and Zingales, 1995; Titman et al, 2003), our firm-level controls include the effective tax rate (EffTax, measured by taxes/net income), asset tangibility (Tang, measured by total assets/fixed assets), return on assets (ROA), and the natural $\log$ of total assets (LNTA). ${ }^{20}$ Given the importance of asset tangibility in environments with a somewhat uncertain legal environment, we include a measure of asset specificity after Acharya, et al (2004): the dummy variable AssetSpec takes a value of 1 for firms in the mining, transportation, and manufacturing industries with high levels of asset specificity (to reflect the likelihood of resale of their assets in the event of bankruptcy relative to the excluded industries of agriculture, wholesale, construction, services, and retail). We also employ country-level control variables as per the countrylevel analysis, above.

\section{Firm-Level Leverage Results}

Table 5 presents the results of our initial, firm-level, econometric analysis. We begin with an OLS specification, presented in column (1). The coefficient on

\footnotetext{
${ }^{20}$ All variables are measured in U.S. dollars at current exchange rates, to allow comparability among firms in countries with different currencies. We are not concerned that exchange rates are driving our results, since most of our firm-level variables are ratios (the only exception is log of total assets).
} 
DeltaEmCred is positive and significant at better than the one percent level, indicating that firms operating in environments with improved creditor rights tend to have increased leverage. The relatively small magnitude of the coefficient (about 1\%) is not surprising, for the reasons given above relating to the speed of adjustment, managerial quality, and recognition of idea ${ }^{21}$ capital structure. Note that rule of law is positive and significant in all specifications, indicating that firms in countries with better legal institutions use more debt financing, ceteris paribus.

An important econometric issue we should consider, however, is that error terms might be clustered by firm. When standard errors in regressions are highly correlated, such clustering should be controlled for so that we are properly stating the standard errors of the estimated parameters. In column (2), therefore, we present results using White's heteroskedastic-constant variance estimations. This robust OLS technique yields somewhat different error terms in the coefficients for effective tax rate, return on assets, $\log$ of per capita GDP, and GDP growth. None of the significance levels on the choice variable coefficients, however, are altered when we use this alternative technique.

\section{INSERT TABLE 4 ABOUT HERE}

\footnotetext{
${ }^{21}$ Fidrmuc and Fidrmuc (2007) find that institutional factors such as lack of skilled management in Central and Eastern Europe can put constraints on value-maximizing behavior, even in closely-held firms with few agency problems. For an examination of how quickly firms in Central and Eastern Europe recognize and achieve their ideal capital structure, see Nivorozhkin, 2005. Flannery and Rangan (2006) find that even in advanced industrialized countries with long-standing traditions of corporate governance, the typical firm only closes one-third of the gap between its actual and target debt ratios each year. Our accounting data are lagged by from one to two years following the change in the EmCred score.
} 
Another econometric issue concerns the fact that our dependent variable long-term debt over total assets is, in fact, censored. ${ }^{22}$ Results from this estimation are presented in column (3) of Table 4. In this specification, the magnitude of the coefficient increases from around $1 \%$ to over $4 \%$, and the level of significance remains very high.

\section{Income Statement Variables and Potential Endogeneity of Effective Tax Rates}

Our use of the effective tax rate variable, although consistent with previous work on cross-country variation in capital structure (Fan, Titman, and Twite, 2003 use a control variable of taxes paid divided by net income), could raise concerns about endogeneity. In the "typical" corporate environment where interest payments are tax deductible, increased leverage could lead to reduced taxes, calling into question the direction of causality from the effective tax rate to the degree of leverage chosen by a firm's management. This simply means that managers choose the level of debt based on the implications for taxation.

There are several considerations that argue against automatic application of this typical perspective in our setting, however. First of all, in many emerging markets where business and politics are intertwined, influential managers might be able to negotiate lower taxes, despite the amount of interest paid as recorded on the income statement. This will to some extent mitigate the importance of the tax shield associated with interest payments. Second, in these countries, many new industrial facilities that have been set up in regional "enterprise zones" make use of lending to finance such expansion, but also

\footnotetext{
${ }^{22}$ It is, of course, possible for the book value of a firm's long-term debt be greater than book value of total assets - thus it is possible that values for the dependent variable could exceed one. Given our truncation procedure, however, we omitted such firms from consideration. Thus, for our tobit empirical tests, our data are left-censored at zero, and right-censored at 1.
} 
face reduced tax rates for several years. In addition, tax authorities in Central and Eastern Europe find it very difficult to collect revenues, and hard-and-fast rules on taxation might not be enforceable in the nascent legal systems we consider. Most telling, and perhaps surprising to those familiar with the typical case of firms located in advanced industrialized settings, several countries in the region do not provide tax deductions for interest payments (PricewaterhouseCoopers, 2001a, 2001b). For all these reasons, endogeneity concerns should be somewhat mitigated. Nevertheless, we will address this issue by including a set of specifications that omit this variable.

Both the return on assets variable (ROA) and the effective tax rate variable (EffTax), in fact, are derived from income statements. One feature of the Amadeus data is that some countries do not report profit and loss information. This means that any specifications in which we include income statement variables (EffTax and ROA) will necessarily exclude a large number of observations from such countries. Omitting the variables measuring the effective tax rate and return on assets therefore allows us to include a large number of observations from firms that did not have income statement (P\&L) information in the Amadeus database. For example, no Russian firm had the requisite information for those two variables. ${ }^{23}$

Columns (4), (5), and (6) of Table 4 present re-estimations of the first three columns, but excluding the income statement variables. By leaving out those two variables, the number of observations increases considerably from 16,946 to 44,286 . The results are quite consistent in that the sign and significance levels of most coefficients remain similar. The magnitude of the coefficient of the DeltaEmCred choice variable increases (from $0.9 \%$ to $1.3 \%$ ) slightly in the OLS and robust OLS specifications, but

\footnotetext{
${ }^{23}$ This also applies for firms in Croatia, Lithuania, and Slovenia, none of which had income statement data.
} 
declines (from $4.1 \%$ to $3.2 \%$ ) somewhat in the tobit estimation. Therefore, even omitting the potentially endogenous variable effective tax rate as well as the other variable derived from income statement data, return on assets, our results are broadly similar.

\section{Magnitude of EmCred Score, Policy Relevance, and Fixed Effects}

We now address two additional econometric issues relating to the magnitude of the EmCred score and to firm-level fixed effects. First of all, use of a dummy variable such as DeltaEmCred, although econometrically appealing, could obscure important differences in the magnitude of change among creditor protection regimes. Consider two countries, one that increases its level of creditor protection score from 2.0 to 2.3 , and another that increases its score from 2.0 to 7.0 . Both countries would receive a " 1 " for the DeltaEmCred variable, obscuring the potentially important difference in magnitude of creditor protection in these different environments.

To capture the variation in magnitude among scores and their changes in different countries, we follow previous research and in some additional specifications include EmCred itself as an independent variable ${ }^{24}$ (as opposed to our previous estimations that used a dummy variable DeltaEmCred taking the value of "1" if EmCred increased). The magnitude of the numbers in this scale is based on qualitative information relating to legal systems. Its three components are CREDCON, COLLAT, and REMEDY; these labels refer to the ability of creditors to control the bankruptcy process, the existence of legal provision on security interests, and the ability of creditors to impose sanctions on managers after bankruptcy proceedings have begun. These components are summed to provide the EmCred variable that ranges in value from 0 to 11.

\footnotetext{
${ }^{24}$ This is the method employed in the country-level analysis of Pistor et al, 2000.
} 
Although this scoring procedure provides information about ranking and order, it might not be the case that the scaling is econometrically meaningful, irrespective of the fact that it has been used as is in previous research. Therefore, these additional estimations using the actual score (as opposed to a dummy reflecting a change in the score) serve the function of testing whether the magnitude of the EmCred variable has meaning in an econometric context in the firm-level data we employ. For these reasons, however, we should be careful about the interpretation of the magnitude of the coefficient for this variable (since, for example, a movement from 1 to 2 could have a different effect on leverage or maturity than a movement from 10 to 11 ).

Second, we wish to consider the policy implications of this research. Previous studies raise the issue as to whether actual enforcement or the laws on the books themselves are more important for determining outcomes. We can examine whether enforcement (rule of law) is a substitute or complement to laws (EmCred) through use of an interactive term. Thus, we specify an additional model as follows:

$$
\begin{aligned}
& \quad(\mathrm{LTD} / \mathrm{TA})_{\mathrm{j}, \mathrm{i}, \mathrm{t}}=\alpha+\beta 1 \operatorname{EffTax}_{\mathrm{j}, \mathrm{i}, \mathrm{t}}+\beta 2 \operatorname{Tang}_{\mathrm{j}, \mathrm{i}, \mathrm{t}}+\beta 3 \mathrm{ROA}_{\mathrm{j}, \mathrm{i}, \mathrm{t}}+\beta 4 \mathrm{LNTA}_{\mathrm{j}, \mathrm{i}, \mathrm{t}}+ \\
& \beta 5 \mathrm{AssetSpec}_{\mathrm{j}, \mathrm{i}, \mathrm{t}}+\beta 6 \mathrm{LnPCgdp}_{\mathrm{i}, \mathrm{t}}+\beta 7 \mathrm{M} 3 / \mathrm{GDP}_{\mathrm{i}, \mathrm{t}}+\beta 8 \mathrm{GDPgrowth}_{\mathrm{i}, \mathrm{t}}+\text { PRuleLaw }_{\mathrm{i}}+ \\
& \beta 10 \mathrm{EmCred}_{\mathrm{i}, \mathrm{t}-1}+\beta 10 \mathrm{EmCred}^{*} \text { RuleLaw }_{\mathrm{i}, \mathrm{t}-1}+\varepsilon
\end{aligned}
$$

where all variables are as described previously, EmCred represents the variable that ranges from 0 to 11 that describes the level of creditor protection, and the final, 
interactive term (EmCred*RuleLaw) is simply the product of that variable and the rule of law score.

Even though use of the EmCred variable helps us distinguish changes in the magnitude of creditor protection, its use in an unbalanced panel of firm-year observations could mask the fact that the composition of firms could be changing over the time period we consider, such that our results do not show changes in the behavior of individual firms over time, but rather demonstrate inclusion of more leveraged firms later on. We therefore employ a firm-level fixed-effects generalize least squares model to provide evidence on whether changes in average leverage are not simply being driven by the changing composition of firms in the sample, but reflect changes in the actual leverage of individual companies.

\section{INSERT TABLE 5 ABOUT HERE}

\section{EmCred Magnitude and GLS Fixed-Effects Findings}

Table 5 presents results including EmCred as an independent variable, and supplement the earlier specifications (OLS, robust OLS, and tobit) with a final, firm-level fixed-effects generalized least squares estimation. We find that the coefficient on EmCred is positive in all models, and statistically significant in all but one of them. The magnitude of the coefficient is lowest in the OLS and robust OLS specifications, and highest when using firm-level fixed effects (column 5). In addition, we see that the coefficient on rule of law is also positive and significant at better than the one percent level in all estimations. Finally, the coefficient on the interactive term is in all cases 
negative and highly significant, indicating that the rule of law and ostensible creditor protection are substitutes in their effect on leverage. This finding has an important policy implication: countries can increase leverage by simply changing laws on the books related to creditor protection, even in an environment where the rule of law and the enforcement of such new rules might be imperfect. Although effective enforcement is important, our findings indicate that its absence will not completely abrogate the effect of an increase in creditor protection on the ability of unlisted firms to obtain credit.

\section{B. Firm-Level Maturity Model}

Our second set of empirical tests examines debt maturity, following the work of Rajan and Zingales (1995), Wald (1999), and Aggarwal and Jamdee (2003), who look at G-7 countries, as well as Booth, et al (2001) and Fan, Titman, and Twite (2003), who examine developing countries. We estimate the following model:

$$
\begin{aligned}
& (\mathrm{LTD} / \mathrm{TD})_{\mathrm{j}, \mathrm{i}, \mathrm{t}}=\alpha+\beta 1 \operatorname{EffTax}_{\mathrm{j}, \mathrm{i}, \mathrm{t}}+\beta 2 \operatorname{Tang}_{\mathrm{j}, \mathrm{i}, \mathrm{t}}+\beta 3 \mathrm{ROA}_{\mathrm{j}, \mathrm{i}, \mathrm{t}}+\beta 4 \mathrm{LNTA}_{\mathrm{j}, \mathrm{i}, \mathrm{t}}+ \\
& \beta 5 \text { AssetSpec }_{\mathrm{j}, \mathrm{i}, \mathrm{t}}+\beta 6 \mathrm{LnPCgdp}_{\mathrm{i}, \mathrm{t}}+\beta 7 \mathrm{M} 3 / \mathrm{GDP}_{\mathrm{i}, \mathrm{t}}+\beta 8 \mathrm{GDPGrowth}_{\mathrm{i}, \mathrm{t}}+ \\
& \beta 9 \text { TermSpread }_{\mathrm{i}, \mathrm{t}}+\beta 10 \text { RuleLaw }+\beta 11 \text { DeltaEmCred }_{\mathrm{i}, \mathrm{t}-1}+\varepsilon
\end{aligned}
$$

where the dependent variable is long-term debt divided by total debt and the independent variables are as defined above. We include an additional variable TermSpread that measures the difference in long-term (lending) from short-term (deposit) rates of interest in the countries we consider, indexed by each country in each year. 


\section{INSERT TABLE 6 ABOUT HERE}

Table 6 reports our debt maturity results, using a set of econometric specifications that mirrors the leverage estimations of Table 4. Across all specifications, we find that debt maturity is positively related to asset tangibility, to size, to asset specificity, and to growth of broad money. In most specifications, the rule of law coefficient is positive and significant. In addition, the coefficient on our choice variable DeltaEmCred is positive and significant, indicating that improvements in creditor rights increase the maturity of debt in our sample of firms.

\section{EXTENSION: LEGAL ORIGIN}

We now extend our findings and turn to whether historical legal origin has an effect on firm-level behavior. Even if the law provides protection, and the courts are efficient at enforcing the rule of law, factors related to legal origin (see Beck, et al, 2003) such as the nature of judicial decision-making and ability of private sector actors to rely on litigation to enforce their rights, could be associated with the levels of debt provided to individual firms. Managers in the four distinct European legal jurisdictions seem to approach debt policy in different ways, according to survey evidence (Bancel and Mittoo, 2004). For the specifications related to legal origin, we simply re-estimate the models from above, but include two additional dummy variables (French and Eurasian) taking the value of 1 for countries with either of these two legal origins, respectively. German origin is the reference (omitted) category. Countries with German legal origin tend to 
have higher levels of overall economic and financial market development relative to the countries further to the south and east in our data set; LnPCgdp should effectively control for this.

\section{INSERT TABLE 7 ABOUT HERE}

In Table 7 we report results of estimations that include these two additional dummy variables relating to legal origin. ${ }^{25}$ Our findings indicate that legal origin matters. In all specifications relating to leverage (columns 1-4), firms located in nonGerman legal origin countries had significantly less leverage. The evidence is somewhat less strong for Eurasian legal origin countries in the debt maturity estimations (columns 5-8). Overall, especially for French legal system countries, we find evidence that legal origin matters. The signs and significance levels for the other variables are generally consistent with the earlier specifications.

\section{CONCLUSION}

Our examination of unlisted companies from the emerging market setting show that higher levels of legal protection for creditors are positively and significantly associated both with the amount of debt assumed by firms, and with its maturity. ${ }^{26} \mathrm{We}$ further find that creditor protection and institutional effectiveness are substitutes regarding their relationship with firm leverage and debt maturity. These findings are

\footnotetext{
${ }^{25}$ We were forced to omit ROE and EffTax due to the fact that Russia is the only country besides Ukraine in the data set to have Eurasian legal origin. Thus, we had to include firm-year observations from Russia, but did not have any income statement data from firms in that country.

${ }^{26} \mathrm{We}$ do not draw any conclusions as to whether better enforcement is more or less important than more protective laws on the books; our study indicates that they are both reflected in firm behavior.
} 
robust to a number of different econometric specifications, firm-level and country-level analysis, and a battery of control variables.

The policy implications of our work are clear for decision-makers who wish to help small- and medium-sized firms obtain access to external finance: they should enact legal reforms in order to better protect the rights of creditors (including those relating to collateral) and increase the rule of law (that is, enforcement of laws on the books). Both types of reform are associated with greater access to external debt finance (potentially allowing more projects to receive funding) and longer maturity debt, which in turn allows firms to limit risk by reducing the volatility of interest payments by allowing them to contract for long-term debt contracts when interest rates are low.

In terms of future research, we believe our findings justify further investigation of time-series data on changes in creditor rights and other legal protections for investors, and how they are reflected in firm-level behavior. There is another existing literature relating to the speed of adjustment of firms to their ideal or target capital structure; our findings indicate that future studies in this area should consider carefully the impact of regulatory changes and laws that affect the use of collateral by creditors. Finally, our results relate to the broad cross-sectional literature on investor protection and external finance, and demonstrate that greater protection for investors can assist even relatively small, unlisted firms to achieve higher levels of access to external finance. 


\section{Appendix: Variable Definitions}

\section{Panel A: Dependent Variables}

\begin{tabular}{|l|l|l|}
\hline Variable: & Definition & Source \\
\hline LTD/TA & Long-Term Debt/Total Assets & \multirow{2}{*}{ Amadeus data base } \\
\hline LTD/TD & Long-Term Debt/Total Debt & \\
\hline
\end{tabular}

\section{Panel B: Independent Variables}

\begin{tabular}{|c|c|c|}
\hline Variable: & Definition & Source \\
\hline EffTax & Effective Tax Rate: Taxes/(EBIT-Interest) & \multirow{4}{*}{ Amadeus data base } \\
\hline Tang & Tangible Assets: Fixed Assets/Total Assets & \\
\hline ROA & Return on Assets & \\
\hline LNTA & Natural Log of Total Assets & \\
\hline LNPCGDP & Log of per capita output & \multirow{4}{*}{ World Bank } \\
\hline Growth & Annual GDP growth rate & \\
\hline M3/GDP & Broad money as a portion of GDP & \\
\hline TermSpread & $\begin{array}{l}\text { Difference between long-term (lending) and short-term } \\
\text { (deposit) rates of interest }\end{array}$ & \\
\hline AssetSpec & $\begin{array}{l}\text { Dummy variable receiving value of } 1 \text { for industries with } \\
\text { high asset specificity (mining, transportation, and } \\
\text { manufacturing) }\end{array}$ & $\begin{array}{l}\text { Amadeus data base and } \\
\text { author calculations }\end{array}$ \\
\hline EmCred & $\begin{array}{l}\text { Sum of three components (CRDCON, COLLAT, and } \\
\text { REMEDY) of creditor rights, specifically designed for } \\
\text { emerging market contexts, } 0 \text { to } 11 \text { scale. See below for } \\
\text { definitions of these three components of this measure. }\end{array}$ & Author calculations \\
\hline RuleLaw & $\begin{array}{l}\text { Expert rating from a survey of regional experts in Central } \\
\text { and Eastern Europe Economic Review, 1998; scores range } \\
\text { from } 1.4 \text { to } 8.7\end{array}$ & $\begin{array}{l}\text { Pistor, Raiser, and } \\
\text { Gelfer, } 2000\end{array}$ \\
\hline TimeTrend & $\begin{array}{l}\text { Takes value of } 1 \text { for } 1997,2 \text { for } 1998,3 \text { for } 1999,4 \text { for } \\
2000 \text {, and } 5 \text { for } 2001\end{array}$ & Author calculations \\
\hline
\end{tabular}

\section{Panel C: Components of EmCred}

\begin{tabular}{|l|l|l|}
\hline CREDCON & $\begin{array}{l}\text { Creditor Rights (values exist for 1992, 1994, 1996, and 1998); based on } \\
\text { Pistor, Raiser, and Gelfer, 2000 alternative methodology; 0 to 5 scale } \\
\text { with judgment leading to non-integer scores for some countries }\end{array}$ & \\
\hline COLLAT & $\begin{array}{l}\text { Collateral Rights (values exist for 1992, 1994, 1996, and 1998); based on } \\
\text { Pistor, Raiser, and Gelfer, 2000 alternative methodology; 0 to 3 scale } \\
\text { with judgment leading to non-integer scores for some countries }\end{array}$ & $\begin{array}{l}\text { Pistor, Raiser, } \\
\text { and Gelfer, }\end{array}$ \\
\cline { 1 - 2 } REMEDY & $\begin{array}{l}\text { Remedy in the case of bankruptcy for the creditor; from Pistor, Raiser, } \\
\text { and Gelfer, 2000; 0 to 3 scale with judgment leading to non-integer } \\
\text { scores for some countries }\end{array}$ & \\
\hline
\end{tabular}




\section{Panel D: Measures of Creditor Rights}

EmCred refers to a measure designed to be more applicable in emerging market settings than the LLSV measure CRED. (The latter assumes clear differentiation of liquidation and reorganization types of bankruptcy which is not generally applicable in the emerging market setting.)

\begin{tabular}{|l|c|c|c|}
\hline & \multicolumn{3}{|c|}{ EmCred } \\
\hline Country & 1994 & 1996 & 1998 \\
\hline Bosnia-Herzegovina & 0 & 0 & 4.75 \\
\hline Bulgaria & 7 & 9 & 9 \\
\hline Croatia & 0 & 8 & 8 \\
\hline Czech Republic & 6 & 6 & 6 \\
\hline Estonia & 8 & 8 & 8 \\
\hline Hungary & 6.75 & 8.75 & 8.75 \\
\hline Latvia & 4.75 & 5.75 & 7 \\
\hline Lithuania & 4.75 & 4.75 & 6 \\
\hline Poland & 6.75 & 6.75 & 8.75 \\
\hline Republic of Macedonia & 1 & 1 & 3 \\
\hline Romania & 0 & 6 & 7 \\
\hline Russian Federation & 4.5 & 5.5 & 8 \\
\hline Slovak Republic & 6.5 & 6.5 & 8 \\
\hline Slovenia & 7.75 & 7.75 & 7.75 \\
\hline Ukraine & 6.75 & 6.75 & 6.75 \\
\hline
\end{tabular}




\section{R E F E R E N C E S}

Acharya, V.; R. Sundaram and K. John, 2004. On the Capital-Structure Implications of Bankruptcy Codes. London Business School working paper.

Aggarwal, R. and Jamdee, S., 2003. Determinants of Capital Structure: Evidence from the G-7 Countries. Kent State University working paper.

Bancel, F. and Mittoo, U., 2004. Cross-Country Determinants of Capital Structure Choice: A Survey of European Firms. Financial Management 33:103-132.

Beck, T., Demirguc-Kunt, A. and Maksimovic, V., 2002. Funding growth in bank-based and market-based financial systems: Evidence from firm level data. Journal of Financial Economics, Vol. 65 (3).

Beck, T., Demirguc-Kunt, A. and Maksimovic, V., 2004. Bank competition and access to finance: International Evidence. Journal of Money, Credit and Banking, Vol. 36, \#6.

Beck, T., Demirguc-Kunt, A. and Maksimovic, V., 2005. Financial and legal constraints to firm growth: Does size matter? The Journal of Finance, Vol. 60, \#1.

Berglöf, E. and P. Bolton, 2002. The 'great divide': financial architecture in transition. Journal of Economic Perspectives Winter 2002, Vol. 16 Issue 1, p77.

Bogdan, M. 1994 Comparative law. Stockholm: Norstedts juridik.

Booth, L; Aivazian, V., Demirguc-Kunt, A., and Maksimovic, V., 2001. Capital Structures in Developing Countries. Journal of Finance 56: 87-130.

Demirgüç-Kunt, A. and V. Maksimovic, 1998. Law, finance, and firm growth. Journal of Finance 53: 2107-37.

Demirgüç-Kunt, A. and V. Maksimovic, 1999. Institutions, financial markets, and firm debt maturity. Journal of Financial Economics 54(3): 295-336.

Demirgüç-Kunt, A. and V. Maksimovic, 2002. Funding growth systems in bank-based and market-based financial systems: evidence from firm-level data. Journal of Financial Economics 65(3): [337]-63.

Desai, M.; Gompers, P. and Lerner, J., 2005. Institutions, Capital Constraints and Entrepreneurial Firm Dynamics: Evidence from Europe. Harvard NOM Working Paper No. 03-59.

Dittmar, A., 2004. Capital Structure in Corporate Spinoffs. Journal of Business 77: 9-43. 
European Bank for Reconstruction and Development, 2000. Transition Report 2000. London: EBRD.

Fan, Joseph P. H., Twite, Garry J. and Titman, S., 2006. An International Comparison of Capital Structure and Debt Maturity Choices. AFA 2005 Philadelphia Meetings Available at SSRN: http://ssrn.com/abstract $=423483$

Fidrmuc, J. and Fidrmuc, J., 2007. Fire the manager to improve performance? Managerial turnover and incentives after privatization in the Czech Republic. Economics of Transition, Vol. 15 (3): 505-533.

Flannery, M. and Rangan, K., 2006. Partial adjustment toward capital structures. Journal of Financial Economics 79: 459 - 506.

Frank, M. and Goyal, V. K., 2005. Tradeoff and Pecking Order Theories of Debt, in B.E. Eckbo (ed.) Handbook of Corporate Finance: Empirical Corporate Finance, NorthHolland Handbooks in Finance Series, Chapter 7.

Gerschenkron, A., 1962. Economic Backwardness in Historical Perspective. Cambridge, Mass., Belknap Press.

Giannetti, M., 2003. Do Better Institutions Mitigate Agency Problems? Evidence from Corporate Finance Choices. Journal of Financial and Quantitative Analysis 39 (1): $185-212$.

Hall, T. and Joergenson, F., 2008. Performance and Ownership Concentration in Europe. Christopher Newport University working paper.

de Haas, R. and Peeters, M., 2006. Firms' dynamic adjustment to target capital structures in Central and Eastern Europe. Economic Transition 14 (1): 133-169.

Hyytinen, A.; I. Kuosa; and T. Takalo 2003 "Law or Finance: Evidence from Finland," European Journal of Law and Economics, 16: 59-89.

Johnson, S.; McMillan, J.; and Woodruff, C., 2002. Property Rights, Finance, and Entrepreneurship, and Finance. American Economic Review, 92(5): 1335-1357.

Ju, N.; Parrino, R.; Poteshman, A.M.; and M. S. Weisbach, 2004. Horses and Rabbits? Trade-Off Theory and Optimal Capital Structure. Journal of Financial and Quantitative Analysis.

Klapper, L., Sarria-Allende, V. and Sulla, V., 2002. Small and Medium-Sized Enterprise Financing, in Eastern Europe. World Bank Working Paper, 2002.

Köke, J. and Schröder, M., 2003. The Prospect of Capital Markets in Central and Eastern Europe. East European Economics, Jul/Aug 2003 41(4): 5-38. 
Krkoska, L., 2001. Foreign Direct Investment Financing of Capital Formation in Central and Eastern Europe. EBRD Working Paper \#67.

La Porta, R., Lopez-de-Silanes, F.; Shleifer, A.; and Vishny, R., 1997. Legal determinants of external finance. The Journal of Finance. Vol. 52, Iss. 3; p. 11311151.

La Porta, R., Lopez-de-Silanes, F.; Shleifer, A.; and Vishny, R., 1998. Law and Finance. Journal of Political Economy 106(6): 1113-55.

La Porta, R. Lopez-de-Silanes, F. and Shleifer, A., 2006. What works in securities laws? Journal of Finance 61 (1): 1-32.

Levine, R., 1998. The Legal Environment, Banks, and Long-Run Economic Growth. Journal of Money, Credit, and Banking, 30.3: 596-613.

Mehrotra, V.; Mikkelson, W. and M. Partch, 2003. The Design of Financial Policies in Corporate Spinoffs. Review of Financial Studies 16, 1359-1388.

Nivorozhkin, E., 2005. Financing choices of firms in EU accession countries. Emerging Markets Review 6 (2): 138-169.

Pistor, K., M. Raiser, and G. Gelfer., 2000. Law and finance in transition economies. Economics of Transition 8(2): 325-68.

PricewaterhouseCoopers, 2001a. Corporate and Individual Taxes Around the World. CDROM \#NY-PD-02-0430-A. , 2001b. "Doing Business and Investing in Countries Worldwide," CD-ROM.

Rajan, R. G. and Zingales, L. 1995. What Do We Know About Capital Structure? Some Evidence from International Data. The Journal of Finance Vol. 50 No. 5: 1421-1460. ,2003. The great reversals: the politics of financial development in the twentieth century. Journal of Financial Economics 69(1): [5]-50.

Slavova, S., 1999. Law and finance in transition economies. London School of Economics and Political Science. LSE Financial Markets Group. Special Paper Series No. 121: 1-48.

Wald, J., 1999. How Firm Characteristics Affect Capital Structure: An International Comparison. The Journal of Financial Research. Vol. 22, Iss. 2: 161-188

Welch, I., 2004. Capital Structure and Stock Returns. Journal of Political Economy 112, 106-31. 
FIGURE 1: Average Balance Sheet, Common Size Format All Figures Expressed in Terms of Total Assets

\begin{tabular}{|cc|cc|}
\hline \multicolumn{2}{|c|}{ Assets } & \multicolumn{2}{|c|}{ Liabilities and Owners' Equity } \\
\hline \multirow{3}{*}{ Current Assets } & \multirow{2}{*}{$54.14 \%$} & $\begin{array}{c}\text { Short-Term } \\
\text { Debt }\end{array}$ & $45.65 \%$ \\
\cline { 3 - 4 } \multirow{2}{*}{$\begin{array}{c}\text { Net Fixed } \\
\text { Assets }\end{array}$} & $\begin{array}{c}\text { Long-Term } \\
\text { Debt }\end{array}$ & $4.90 \%$ \\
\cline { 3 - 4 } Total Assets & \multirow{2}{*}{$45.86 \%$} & Total Liabilities & $50.55 \%$ \\
\cline { 3 - 4 } & \multirow{2}{*}{$100 \%$} & $\begin{array}{c}\text { Total Liabilities } \\
\text { and Equity }\end{array}$ & $100 \%$ \\
\hline
\end{tabular}


TABLE 1: Descriptive Statistics

\section{Panel A: Descriptive Statistics of LTD/TA for All Firms, All Years}

\begin{tabular}{|l|c|c|c|c|c|c|}
\hline Country & $\begin{array}{c}\text { Number } \\
\text { of Firms }\end{array}$ & $\begin{array}{c}\text { Firm-Year } \\
\text { Observations }\end{array}$ & Mean & $\begin{array}{c}\text { Standard } \\
\text { Deviation }\end{array}$ & Minimum & Maximum \\
\hline Bosnia-Herzegovina & 137 & 137 & $3.92 \%$ & $9.52 \%$ & 0 & $62.61 \%$ \\
\hline Bulgaria & 904 & 3,332 & $3.15 \%$ & $10.31 \%$ & 0 & $94.76 \%$ \\
\hline Croatia & 218 & 513 & 0 & 0 & 0 & 0 \\
\hline Czech Republic & 1,526 & 5,192 & $10.18 \%$ & $15.79 \%$ & 0 & $93.34 \%$ \\
\hline Estonia & 220 & 883 & $9.45 \%$ & $13.94 \%$ & 0 & $83.90 \%$ \\
\hline Hungary & 575 & 1,826 & $0.83 \%$ & $5.07 \%$ & 0 & $73.33 \%$ \\
\hline Latvia & 417 & 1,623 & $12.59 \%$ & $17.44 \%$ & 0 & $88.15 \%$ \\
\hline Lithuania & 108 & 314 & $12.04 \%$ & $14.08 \%$ & 0 & $89.30 \%$ \\
\hline Poland & 2,275 & 5,720 & $8.86 \%$ & $12.92 \%$ & 0 & $91.85 \%$ \\
\hline Romania & 2,048 & 8,641 & $3.04 \%$ & $9.71 \%$ & 0 & $92.96 \%$ \\
\hline Russian Federation & 4,336 & 8,272 & $2.03 \%$ & $8.06 \%$ & 0 & $94.24 \%$ \\
\hline Slovak Republic & 380 & 1,088 & $9.16 \%$ & $13.11 \%$ & 0 & $82.62 \%$ \\
\hline Slovenia & 148 & 394 & 0 & 0 & 0 & 0 \\
\hline Ukraine & 3,234 & 9,729 & $3.23 \%$ & $8.43 \%$ & 0 & $88.34 \%$ \\
\hline Total: & 16,526 & 47,664 & $4.89 \%$ & $11.40 \%$ & 0 & $94.76 \%$ \\
\hline
\end{tabular}

\section{Panel B: Descriptive Statistics of LTD/TD for All Firms, All Years}

\begin{tabular}{|l|c|c|c|c|c|c|}
\hline Country & $\begin{array}{c}\text { Number } \\
\text { of Firms }\end{array}$ & $\begin{array}{c}\text { Firm-Year } \\
\text { Observations }\end{array}$ & Mean & $\begin{array}{c}\text { Standard } \\
\text { Deviation }\end{array}$ & Minimum & Maximum \\
\hline Bosnia-Herzegovina & 137 & 137 & 10.11 & 19.20 & 0 & $86.67 \%$ \\
\hline Bulgaria & 904 & 3,299 & 5.81 & 17.09 & 0 & $100 \%$ \\
\hline Croatia & 218 & 511 & 0 & 0 & 0 & 0 \\
\hline Czech Republic & 1,526 & 5,155 & 11.57 & 22.33 & 0 & $100 \%$ \\
\hline Estonia & 220 & 880 & 14.93 & 19.75 & 0 & $91.05 \%$ \\
\hline Hungary & 575 & 1,823 & 1.38 & 7.37 & 0 & $88.42 \%$ \\
\hline Latvia & 417 & 1,620 & 19.81 & 24.09 & 0 & $100 \%$ \\
\hline Lithuania & 108 & 314 & 22.83 & 21.10 & 0 & $97.99 \%$ \\
\hline Poland & 2,275 & 5,720 & 13.73 & 17.96 & 0 & $96.39 \%$ \\
\hline Romania & 2,048 & 8,607 & 5.07 & 14.72 & 0 & $100 \%$ \\
\hline Russian Federation & 4,336 & 8,271 & 3.74 & 12.65 & 0 & $98.36 \%$ \\
\hline Slovak Republic & 380 & 1,087 & 16.36 & 21.05 & 0 & $94.19 \%$ \\
\hline Slovenia & 148 & 388 & 0 & 0 & 0 & 0 \\
\hline Ukraine & 3,234 & 9,711 & 7.17 & 15.22 & 0 & $96.77 \%$ \\
\hline Total: & 16,526 & 47,521 & 8.44 & 17.30 & 0 & $100 \%$ \\
\hline
\end{tabular}


TABLE 1: Descriptive Statistics, Continued

Panel C: LTD/TA by Country: Observations and Mean value

\begin{tabular}{|l|cc|cc|cc|cc|c|c|}
\hline & \multicolumn{2}{|c|}{1997} & \multicolumn{2}{|c|}{$\mathbf{1 9 9 8}$} & \multicolumn{2}{c|}{$\mathbf{1 9 9 9}$} & \multicolumn{2}{c|}{$\mathbf{2 0 0 0}$} & \multicolumn{2}{|c|}{$\mathbf{2 0 0 1}$} \\
\hline & Obs & Mean & Obs & Mean & Obs & Mean & Obs & Mean & Obs & Mean \\
\hline $\begin{array}{l}\text { Bosnia- } \\
\text { Herzigovina }\end{array}$ & 0 & -- & 0 & -- & 137 & $3.92 \%$ & 0 & -- & 0 \\
\hline Bulgaria & 386 & $2.44 \%$ & 611 & $2.19 \%$ & 722 & $2.94 \%$ & 786 & $3.54 \%$ & 827 & $4.02 \%$ \\
\hline Croatia & 18 & 0 & 130 & 0 & 142 & 0 & 105 & 0 & 118 & 0 \\
\hline $\begin{array}{l}\text { Czech } \\
\text { Republic }\end{array}$ & 906 & $10.82 \%$ & 1,013 & $11.16 \%$ & 1,294 & $10.28 \%$ & 1,294 & $9.70 \%$ & 685 & $8.60 \%$ \\
\hline Estonia & 143 & $10.26 \%$ & 168 & $9.56 \%$ & 188 & $9.72 \%$ & 203 & $9.11 \%$ & 181 & $8.79 \%$ \\
\hline Hungary & 292 & $0.86 \%$ & 361 & $0.40 \%$ & 432 & $1.25 \%$ & 449 & $1.18 \%$ & 292 & $0.19 \%$ \\
\hline Latvia & 238 & $10.58 \%$ & 303 & $11.55 \%$ & 340 & $12.43 \%$ & 367 & $12.82 \%$ & 375 & $14.62 \%$ \\
\hline Lithuania & 46 & $13.48 \%$ & 59 & $12.10 \%$ & 66 & $12.62 \%$ & 75 & $11.21 \%$ & 68 & $11.36 \%$ \\
\hline Poland & 642 & $8.19 \%$ & 1,094 & $9.20 \%$ & 1,418 & $9.46 \%$ & 1,450 & $8.64 \%$ & 1,116 & $8.43 \%$ \\
\hline Romania & 1,582 & $2.37 \%$ & 1,700 & $2.68 \%$ & 1,742 & $3.21 \%$ & 1,801 & $3.47 \%$ & 1,816 & $3.39 \%$ \\
\hline $\begin{array}{l}\text { Russian } \\
\text { Federation }\end{array}$ & 0 & -- & 2,102 & $1.67 \%$ & 512 & $2.89 \%$ & 2,287 & $1.90 \%$ & 3,371 & $2.21 \%$ \\
\hline $\begin{array}{l}\text { Slovak } \\
\text { Republic }\end{array}$ & 161 & $10.33 \%$ & 203 & $8.71 \%$ & 248 & $9.29 \%$ & 274 & $9.01 \%$ & 202 & $8.63 \%$ \\
\hline Slovenia & 74 & 0 & 86 & 0 & 88 & 0 & 65 & 0 & 81 \\
\hline Ukraine & 2 & 0 & 1,198 & $2.61 \%$ & 2,645 & $2.85 \%$ & 2,984 & $2.92 \%$ & 2,900 & $4.17 \%$ \\
\hline Total: & 4,490 & $5.85 \%$ & 9,028 & $4.61 \%$ & 9,974 & $5.39 \%$ & 12,140 & $4.74 \%$ & 12,032 & $4.48 \%$ \\
\hline
\end{tabular}

Panel D: LTD/TD by Country: Observations and Mean value

\begin{tabular}{|c|c|c|c|c|c|c|c|c|c|c|}
\hline & \multicolumn{2}{|c|}{1997} & \multicolumn{2}{|c|}{1998} & \multicolumn{2}{|c|}{1999} & \multicolumn{2}{|c|}{2000} & \multicolumn{2}{|c|}{2001} \\
\hline & Obs & Mean & Obs & Mean & Obs & Mean & Obs & Mean & Obs & Mean \\
\hline $\begin{array}{l}\text { Bosnia- } \\
\text { Herzigovina }\end{array}$ & 0 & -- & 0 & -- & 137 & $10.11 \%$ & 0 & -- & 0 & -- \\
\hline Bulgaria & 381 & $3.84 \%$ & 599 & $4.51 \%$ & 713 & $5.67 \%$ & 781 & $6.32 \%$ & 825 & $7.30 \%$ \\
\hline Croatia & 18 & 0 & 129 & 0 & 141 & 0 & 105 & 0 & 118 & 0 \\
\hline $\begin{array}{l}\text { Czech } \\
\text { Republic }\end{array}$ & 896 & 0 & 1,005 & $17.86 \%$ & 1,280 & $16.57 \%$ & 1,288 & $15.62 \%$ & 684 & $14.25 \%$ \\
\hline Estonia & 143 & $12.24 \%$ & 168 & $14.93 \%$ & 187 & $15.57 \%$ & 201 & $14.53 \%$ & 181 & $14.56 \%$ \\
\hline Hungary & 290 & $15.10 \%$ & 360 & $0.78 \%$ & 432 & $2.03 \%$ & 449 & $1.80 \%$ & 292 & $0.40 \%$ \\
\hline Latvia & 238 & $1.38 \%$ & 301 & $18.68 \%$ & 340 & $19.32 \%$ & 367 & $20.51 \%$ & 374 & $22.15 \%$ \\
\hline Lithuania & 46 & $17.16 \%$ & 59 & $21.96 \%$ & 66 & $24.10 \%$ & 75 & $21.49 \%$ & 68 & $22.33 \%$ \\
\hline Poland & 642 & $13.30 \%$ & 1,094 & $14.48 \%$ & 1,418 & $14.05 \%$ & 1,450 & $13.20 \%$ & 1,116 & $13.52 \%$ \\
\hline Romania & 1,574 & $4.00 \%$ & 1,688 & $4.61 \%$ & 1,734 & $5.36 \%$ & 1,797 & $5.54 \%$ & 1,814 & $5.66 \%$ \\
\hline $\begin{array}{l}\text { Russian } \\
\text { Federation }\end{array}$ & 0 & -- & 2,102 & $3.59 \%$ & 512 & $5.04 \%$ & 2,286 & $3.47 \%$ & 3,371 & $3.81 \%$ \\
\hline $\begin{array}{l}\text { Slovak } \\
\text { Republic }\end{array}$ & 161 & $17.88 \%$ & 202 & $15.24 \%$ & 248 & $15.98 \%$ & 274 & $16.37 \%$ & 118 & $8.66 \%$ \\
\hline Slovenia & 72 & 0 & 84 & 0 & 86 & 0 & 65 & 0 & 81 & 0 \\
\hline Ukraine & 2 & 0 & 1,196 & $6.39 \%$ & 2,641 & $6.43 \%$ & 2,973 & $6.11 \%$ & 2,899 & $9.26 \%$ \\
\hline Total: & 4,463 & $9.70 \%$ & 8,987 & $8.04 \%$ & 9,935 & $9.19 \%$ & 12,111 & $8.06 \%$ & 12,025 & $8.05 \%$ \\
\hline
\end{tabular}


TABLE 1: Descriptive Statistics, Continued

Panel E: Mean Values of Country-Level Variables

\begin{tabular}{|l|c|c|c|c|}
\hline Country & RuleLaw & EmCred & DeltaEmCred & Legal Origin \\
\hline Bosnia-Herz. & 2.10 & 2.85 & 0 & French \\
\hline Bulgaria & 5.90 & 9 & 0 & French \\
\hline Croatia & 7.00 & 8 & 0 & German \\
\hline Czech Republic & 8.30 & 6 & 0 & German \\
\hline Estonia & 8.50 & 8 & 0 & German \\
\hline Hungary & 8.70 & 8.75 & 0 & German \\
\hline Latvia & 7.50 & 6.5 & 0.667 & German \\
\hline Lithuania & 7.20 & 5.5 & 0.666 & German \\
\hline Poland & 8.70 & 7.95 & 0.697 & French \\
\hline Romania & 5.60 & 6.6 & 0 & Eurasian \\
\hline Russian Fed. & 3.70 & 7 & 0.746 & German \\
\hline Slovak Republic & 6.40 & 7.4 & 0.665 & German \\
\hline Slovenia & 8.40 & 7.75 & 0 & Eurasian \\
\hline Ukraine & 3.40 & 6.75 & 0 & \\
\hline
\end{tabular}


TABLE 2: Country-Level Data

\begin{tabular}{|l|c|c|c|c|}
\hline Country & $\begin{array}{c}\text { Log of per capita } \\
\text { output }\end{array}$ & $\begin{array}{c}\text { Liquidity } \\
\text { (M3/GDP) }\end{array}$ & GDP Growth & $\begin{array}{c}\text { Interest rate term } \\
\text { spread }\end{array}$ \\
\hline Bulgaria & 7.56 & 30.94 & 2.03 & 14.73 \\
\hline Czech Republic & 8.75 & 69.27 & 1.00 & 4.45 \\
\hline Estonia & 8.38 & 35.82 & 5.50 & 5.37 \\
\hline Hungary & 8.69 & 49.70 & 4.52 & 4.18 \\
\hline Latvia & 8.01 & 27.17 & 6.15 & 8.18 \\
\hline Lithuania & 8.05 & 20.69 & 4.99 & 7.16 \\
\hline Poland & 8.34 & 39.86 & 4.14 & 6.01 \\
\hline Romania & 7.56 & 23.41 & -1.24 & $\mathrm{n} / \mathrm{a}$ \\
\hline Russian Federation & 7.93 & 27.54 & 4.03 & 20.44 \\
\hline Slovak Republic & 8.52 & 64.34 & 3.08 & 5.61 \\
\hline Ukraine & 7.05 & 19.10 & 1.98 & 29.30 \\
\hline
\end{tabular}


TABLE 3: Regression Results for Country-Level Data ( $p$-values in parentheses)

\begin{tabular}{|c|c|c|c|c|c|c|c|c|}
\hline & (1) & (2) & (3) & (4) & (5) & (6) & (7) & (8) \\
\hline $\begin{array}{l}\text { Dependent } \\
\text { Variable }\end{array}$ & \multicolumn{4}{|c|}{ Long-Term Debt / Total Assets } & \multicolumn{4}{|c|}{ Long-Term Debt / Total Debt } \\
\hline Estimation & OLS & $\begin{array}{c}\text { Robust } \\
\text { OLS }\end{array}$ & Tobit & GLS & OLS & $\begin{array}{c}\text { Robust } \\
\text { OLS }\end{array}$ & Tobit & GLS \\
\hline Constant & $\begin{array}{c}-0.057 \\
(546)\end{array}$ & $\begin{array}{l}-0.057 \\
(0.506) \\
\end{array}$ & $\begin{array}{l}-0.057 \\
(0.506)\end{array}$ & $\begin{array}{l}0.050^{\dagger} \\
(0.126) \\
\end{array}$ & $\begin{array}{c}-0.003 \\
(0.985)\end{array}$ & $\begin{array}{l}-0.003 \\
(0.983)\end{array}$ & $\begin{array}{l}-0.003 \\
(0.983)\end{array}$ & $\begin{array}{c}-0.003 \\
(0.985)\end{array}$ \\
\hline EffTax & $\begin{array}{c}-0.009 \\
(0.603) \\
\end{array}$ & $\begin{array}{l}-0.009 \\
(0.422)\end{array}$ & $\begin{array}{l}-0.009 \\
(0.567)\end{array}$ & $\begin{array}{c}-0.003 \\
(0.489)\end{array}$ & $\begin{array}{l}-0.029 \\
(0.319)\end{array}$ & $\begin{array}{l}-0.029 \\
(0.190)\end{array}$ & $\begin{array}{l}-0.029 \\
(0.258)\end{array}$ & $\begin{array}{l}-0.029 \\
(0.310)\end{array}$ \\
\hline LnPCgdp & $\begin{array}{c}0.009 \\
(0.580)\end{array}$ & $\begin{array}{c}0.009 \\
(0.558)\end{array}$ & $\begin{array}{c}0.009 \\
(0.542)\end{array}$ & $\begin{array}{c}0.002 \\
(0.559)\end{array}$ & $\begin{array}{c}0.030 \\
(0.353)\end{array}$ & $\begin{array}{c}0.030 \\
(0.403)\end{array}$ & $\begin{array}{c}0.030 \\
(0.291)\end{array}$ & $\begin{array}{c}0.030 \\
(0.344)\end{array}$ \\
\hline M3/GDP & $\begin{array}{c}0.001 \\
(0.204)\end{array}$ & $\begin{array}{l}0.001^{\dagger} \\
(0.139)\end{array}$ & $\begin{array}{c}0.001 \\
(0.163)\end{array}$ & $\begin{array}{c}-0.000 \\
(0.769)\end{array}$ & $\begin{array}{c}0.000 \\
(0.897)\end{array}$ & $\begin{array}{c}0.000 \\
(0.906)\end{array}$ & $\begin{array}{c}0.000 \\
(0.883)\end{array}$ & $\begin{array}{c}0.000 \\
(0.896)\end{array}$ \\
\hline GDP growth & $\begin{array}{c}0.002 \\
(0.207)\end{array}$ & $\begin{array}{l}0.002^{\dagger} \\
(0.105)\end{array}$ & $\begin{array}{c}0.002 \\
(0.166)\end{array}$ & $\begin{array}{c}0.000 \\
(0.559)\end{array}$ & $\begin{array}{c}0.000 \\
(0.988)\end{array}$ & $\begin{array}{l}-0.000 \\
(0.988)\end{array}$ & $\begin{array}{l}-0.000 \\
(0.987)\end{array}$ & $\begin{array}{l}-0.000 \\
(0.988)\end{array}$ \\
\hline Term Spread & -- & -- & -- & -- & $\begin{array}{c}-0.002 \\
(0.391) \\
\end{array}$ & $\begin{array}{l}-0.002 \\
(0.342) \\
\end{array}$ & $\begin{array}{l}-0.002 \\
(0.330) \\
\end{array}$ & $\begin{array}{c}-0.002 \\
(0.383) \\
\end{array}$ \\
\hline DeltaEmCred & $\begin{array}{c}0.030 * * \\
(0.042)\end{array}$ & $\begin{array}{c}0.030 * * \\
(0.034)\end{array}$ & $\begin{array}{c}0.030 * * \\
(0.026)\end{array}$ & $\begin{array}{c}0.003 \\
(0.559)\end{array}$ & $\begin{array}{c}0.073 * * \\
(0.013)\end{array}$ & $\begin{array}{c}0.073 * * * \\
(0.005)\end{array}$ & $\begin{array}{c}0.073 * * * \\
(0.005)\end{array}$ & $\begin{array}{c}0.073 * * * \\
(0.008)\end{array}$ \\
\hline Rule of Law & $\begin{array}{c}0.002 \\
(0.733) \\
\end{array}$ & $\begin{array}{c}0.002 \\
(0.698) \\
\end{array}$ & $\begin{array}{c}0.002 \\
(0.707) \\
\end{array}$ & -- & $\begin{array}{c}-0.015 \\
(0.326) \\
\end{array}$ & $\begin{array}{l}-0.015 \\
(0.346)\end{array}$ & $\begin{array}{l}-0.015 \\
(0.264) \\
\end{array}$ & -- \\
\hline $\mathbf{R}^{2}$ & \multicolumn{4}{|c|}{$32.45 \%$} & \multicolumn{4}{|c|}{$32.29 \%$} \\
\hline Obs & \multicolumn{4}{|c|}{40} & \multicolumn{4}{|c|}{35} \\
\hline $\begin{array}{l}\text { F-statistic, LR Chi } \\
\text { or Wald Chi }\end{array}$ & $\begin{array}{l}2.64 * * \\
(0.033) \\
\end{array}$ & $\begin{array}{c}11.91 * * * \\
(0.000)\end{array}$ & $\begin{array}{l}15.69 * * \\
(0.016)\end{array}$ & $\begin{array}{c}0.47 \\
(0.797) \\
\end{array}$ & $\begin{array}{c}1.84 \\
(0.1204)\end{array}$ & $\begin{array}{l}7.39 * * * \\
(0.000)\end{array}$ & $\begin{array}{l}13.65 * \\
(0.058)\end{array}$ & $\begin{array}{c}12.87 * \\
(0.0753)\end{array}$ \\
\hline
\end{tabular}

$\dagger, *, * *$, and $* * *$ indicate significance at the $15 \%, 10 \%, 5 \%$ and $1 \%$ levels, respectively 
TABLE 4: Regression Results for Firm-Level Data (p-values in parentheses)

\begin{tabular}{|c|c|c|c|c|c|c|}
\hline & (1) & (2) & (3) & (4) & (5) & (6) \\
\hline Dependent Variable & \multicolumn{6}{|c|}{ Long-Term Debt / Total Assets } \\
\hline Estimation & OLS & Robust OLS & Tobit & OLS & Robust OLS & Tobit \\
\hline Constant & $\begin{array}{c}-0.086^{* * *} \\
(0.000) \\
\end{array}$ & $\begin{array}{c}-0.086^{* * *} \\
(0.000)\end{array}$ & $\begin{array}{c}-0.476^{* * *} \\
(0.000)\end{array}$ & $\begin{array}{c}-0.017 * * \\
(0.029) \\
\end{array}$ & $\begin{array}{c}-0.017 * * \\
(0.020)\end{array}$ & $\begin{array}{c}-0.170 * * * \\
(0.000)\end{array}$ \\
\hline EffTax & $\begin{array}{l}-0.000 \\
(0.651)\end{array}$ & $\begin{array}{l}-0.000 \\
(0.560)\end{array}$ & $\begin{array}{l}-0.000 \\
(0.921) \\
\end{array}$ & -- & -- & -- \\
\hline Tang & $\begin{array}{c}0.093 * * * \\
(0.000) \\
\end{array}$ & $\begin{array}{c}0.093 * * * \\
(0.000)\end{array}$ & $\begin{array}{c}0.209 * * * \\
(0.000)\end{array}$ & $\begin{array}{c}0.062 * * * \\
(0.000)\end{array}$ & $\begin{array}{c}0.062 * * * \\
(0.000)\end{array}$ & $\begin{array}{c}0.177 * * * \\
(0.000)\end{array}$ \\
\hline ROA & $\begin{array}{c}-0.014 * * * \\
(0.000)\end{array}$ & $\begin{array}{c}-0.014 * * * \\
(0.000)\end{array}$ & $\begin{array}{c}-0.030^{* * *} \\
(0.000)\end{array}$ & -- & -- & -- \\
\hline LnTA & $\begin{array}{c}0.006^{* * *} \\
(0.000) \\
\end{array}$ & $\begin{array}{c}0.006^{* * * *} \\
(0.000)\end{array}$ & $\begin{array}{c}0.028 * * * \\
(0.000)\end{array}$ & $\begin{array}{c}0.006^{* * *} \\
(0.000)\end{array}$ & $\begin{array}{c}0.006^{* * *} \\
(0.000)\end{array}$ & $\begin{array}{c}0.036 * * * \\
(0.000)\end{array}$ \\
\hline AssetSpec & $\begin{array}{c}0.016 * * * \\
(0.000)\end{array}$ & $\begin{array}{c}0.016^{* * *} \\
(0.000)\end{array}$ & $\begin{array}{c}0.034 * * * \\
(0.000)\end{array}$ & $\begin{array}{c}0.008 * * * \\
(0.000)\end{array}$ & $\begin{array}{c}0.008 * * * \\
(0.000)\end{array}$ & $\begin{array}{c}0.023 * * * \\
(0.000)\end{array}$ \\
\hline LnPCgdp & $\begin{array}{c}-0.004 * \\
(0.085)\end{array}$ & $\begin{array}{l}-0.004 * \\
(0.070)\end{array}$ & $\begin{array}{c}-0.016^{* * *} \\
(0.002)\end{array}$ & $\begin{array}{c}-0.014 * * * \\
(0.000)\end{array}$ & $\begin{array}{c}-0.014 * * * \\
(0.000)\end{array}$ & $\begin{array}{c}-0.078 * * * \\
(0.000)\end{array}$ \\
\hline M3/GDP & $\begin{array}{c}0.001 * * * \\
(0.000)\end{array}$ & $\begin{array}{c}0.001 * * * \\
(0.000)\end{array}$ & $\begin{array}{c}0.002 * * * \\
(0.000)\end{array}$ & $\begin{array}{c}0.001^{* * *} * \\
(0.000)\end{array}$ & $\begin{array}{c}0.001 * * * \\
(0.000)\end{array}$ & $\begin{array}{c}0.002^{* * *} \\
(0.000)\end{array}$ \\
\hline GDP growth & $\begin{array}{l}-0.000 \\
(0.472) \\
\end{array}$ & $\begin{array}{l}-0.000 \\
(0.444) \\
\end{array}$ & $\begin{array}{c}0.003 \\
(0.444) \\
\end{array}$ & $\begin{array}{c}0.001 * * * \\
(0.000)\end{array}$ & $\begin{array}{c}0.001 * * * \\
(0.000)\end{array}$ & $\begin{array}{c}0.005 * * * \\
(0.000) \\
\end{array}$ \\
\hline RuleLaw & $\begin{array}{c}0.007 * * * \\
(0.000)\end{array}$ & $\begin{array}{c}0.007 * * * \\
(0.000)\end{array}$ & $\begin{array}{c}0.021 * * * \\
(0.000)\end{array}$ & $\begin{array}{c}0.013^{* * *} * \\
(0.000)\end{array}$ & $\begin{array}{c}0.013 * * * \\
(0.000)\end{array}$ & $\begin{array}{c}0.040 * * * \\
(0.000)\end{array}$ \\
\hline DeltaEmCred & $\begin{array}{c}0.009 * * * \\
(0.002) \\
\end{array}$ & $\begin{array}{c}0.009 * * * \\
(0.002) \\
\end{array}$ & $\begin{array}{c}0.041 * * * \\
(0.000) \\
\end{array}$ & $\begin{array}{c}0.013^{* * *} * \\
(0.000)\end{array}$ & $\begin{array}{c}0.013 * * * \\
(0.000) \\
\end{array}$ & $\begin{array}{c}0.032 * * * \\
(0.000)\end{array}$ \\
\hline $\mathbf{R}^{2}$ & \multicolumn{2}{|c|}{$9.04 \%$} & $30.49 \%$ & \multicolumn{2}{|c|}{$8.45 \%$} & $29.86 \%$ \\
\hline Obs & \multicolumn{3}{|c|}{16,946} & \multicolumn{3}{|c|}{44,286} \\
\hline Firms & \multicolumn{3}{|c|}{6,392} & \multicolumn{3}{|c|}{15,617} \\
\hline Wald Chi ${ }^{2}$ & $\begin{array}{c}167.39 * * * \\
(0.000)\end{array}$ & $\begin{array}{c}136.68 * * * \\
(0.000)\end{array}$ & $\begin{array}{c}2,866.72 * * * \\
(0.000)\end{array}$ & $\begin{array}{c}510.97 * * * \\
(0.000)\end{array}$ & $\begin{array}{c}397.07 * * * \\
(0.000)\end{array}$ & $\begin{array}{c}7,752.03 * * * \\
(0.000)\end{array}$ \\
\hline
\end{tabular}

$\dagger, *, * *$, and $* * *$ indicate significance at the $15 \%, 10 \%, 5 \%$ and $1 \%$ levels, respectively 
TABLE 5: Regression Results for Firm-Level Data, Alternative Specifications

\begin{tabular}{|c|c|c|c|c|c|}
\hline & (1) & (2) & (3) & (4) & (5) \\
\hline Dependent Variable & \multicolumn{5}{|c|}{ Long Term Debt / Total Assets } \\
\hline Estimation & OLS & Robust OLS & Tobit & GLS Tobit & $\begin{array}{c}\text { GLS with Firm- } \\
\text { Level Fixed } \\
\text { Effects }\end{array}$ \\
\hline Constant & $\begin{array}{c}-0.203 * * * \\
(0.000)\end{array}$ & $\begin{array}{c}-0.203 * * * \\
(0.000) \\
\end{array}$ & $\begin{array}{c}-0.472 * * * \\
(0.000) \\
\end{array}$ & $\begin{array}{c}-0.810 * * * \\
(0.000)\end{array}$ & $\begin{array}{c}-0.167 * * * \\
(0.000) \\
\end{array}$ \\
\hline EffTax & $\begin{array}{c}-0.000 \\
(0.828) \\
\end{array}$ & $\begin{array}{l}-0.000 \\
(0.790) \\
\end{array}$ & $\begin{array}{c}0.001 \\
(0.332) \\
\end{array}$ & $\begin{array}{c}0.000 \\
(0.918) \\
\end{array}$ & $\begin{array}{l}-0.000 \\
(0.347) \\
\end{array}$ \\
\hline Tang & $\begin{array}{c}0.095 * * * \\
(0.000)\end{array}$ & $\begin{array}{c}0.095 * * * \\
(0.000)\end{array}$ & $\begin{array}{c}0.213 * * * \\
(0.000)\end{array}$ & $\begin{array}{c}0.189 * * * \\
(0.000) \\
\end{array}$ & $\begin{array}{c}0.080 * * * \\
(0.000) \\
\end{array}$ \\
\hline ROA & $\begin{array}{c}-0.014 * * * \\
(0.000)\end{array}$ & $\begin{array}{l}-0.014 * \\
(0.061)\end{array}$ & $\begin{array}{c}-0.030 * * * \\
(0.000)\end{array}$ & $\begin{array}{c}-0.033 * * * \\
(0.000)\end{array}$ & $\begin{array}{c}-0.044 * * * \\
(0.000)\end{array}$ \\
\hline LnTA & $\begin{array}{c}0.007 * * * \\
(0.000) \\
\end{array}$ & $\begin{array}{c}0.007 * * * \\
(0.000)\end{array}$ & $\begin{array}{c}0.029 * * * \\
(0.000)\end{array}$ & $\begin{array}{c}0.035 * * * \\
(0.000)\end{array}$ & $\begin{array}{c}0.015^{* * * *} \\
(0.000)\end{array}$ \\
\hline AssetSpec & $\begin{array}{c}0.016^{* * * *} \\
(0.000) \\
\end{array}$ & $\begin{array}{c}0.016^{* * *} \\
(0.000) \\
\end{array}$ & $\begin{array}{c}0.034 * * * \\
(0.000)\end{array}$ & $\begin{array}{c}0.030 * * * \\
(0.000) \\
\end{array}$ & -- \\
\hline LnPCgdp & $\begin{array}{c}-0.006 * * * \\
(0.026)\end{array}$ & $\begin{array}{c}-0.006 * * * \\
(0.020) \\
\end{array}$ & $\begin{array}{c}-0.027 * * * \\
(0.000)\end{array}$ & $\begin{array}{l}-0.000 \\
(0.986)\end{array}$ & $\begin{array}{c}0.008^{* * * *} \\
(0.000)\end{array}$ \\
\hline M3/GDP & $\begin{array}{c}0.0003 * * * \\
(0.001)\end{array}$ & $\begin{array}{c}0.0003 * * * \\
(0.001)\end{array}$ & $\begin{array}{c}0.001 * * * \\
(0.000)\end{array}$ & $\begin{array}{c}0.001 * * * \\
(0.003)\end{array}$ & $\begin{array}{c}-0.001 * * * \\
(0.007)\end{array}$ \\
\hline GDP growth & $\begin{array}{c}0.001 * * * \\
(0.003) \\
\end{array}$ & $\begin{array}{c}0.001^{* * *} \\
(0.002) \\
\end{array}$ & $\begin{array}{c}0.005^{* * * *} \\
(0.000)\end{array}$ & $\begin{array}{c}0.002 * * * \\
(0.000)\end{array}$ & $\begin{array}{l}-0.001 * \\
(0.094)\end{array}$ \\
\hline RuleLaw & $\begin{array}{c}0.036 * * * \\
(0.000)\end{array}$ & $\begin{array}{c}0.036^{* * *} \\
(0.000)\end{array}$ & $\begin{array}{c}0.056^{* * * *} \\
(0.000)\end{array}$ & $\begin{array}{c}0.061 * * * \\
(0.000)\end{array}$ & -- \\
\hline EmCred & $\begin{array}{c}0.015^{* * * *} \\
(0.000)\end{array}$ & $\begin{array}{c}0.015 * * * \\
(0.000)\end{array}$ & $\begin{array}{c}0.002 \\
(0.840) \\
\end{array}$ & $\begin{array}{c}0.031 * * * \\
(0.001)\end{array}$ & $\begin{array}{c}0.046^{* * * *} \\
(0.000)\end{array}$ \\
\hline EmCred*Rule of Law & $\begin{array}{c}-0.003 * * * \\
(0.000)\end{array}$ & $\begin{array}{c}-0.003 * * * \\
(0.000) \\
\end{array}$ & $\begin{array}{c}-0.002 * * * \\
(0.000) \\
\end{array}$ & $\begin{array}{c}-0.005^{*} * * \\
(0.000)\end{array}$ & $\begin{array}{c}-0.006^{* * *} \\
(0.000) \\
\end{array}$ \\
\hline Observations & & & 16,846 & & \\
\hline $\mathbf{R}^{2}$ or Pseudo $\mathbf{R}^{2}$ & & & $30.84 \%$ & -- & $0.57 \%$ \\
\hline F-Stat or Wald Chi ${ }^{2}$ & $\begin{array}{c}161.39 * * * \\
(0.000)\end{array}$ & $\begin{array}{c}125.31 * * * \\
(0.000)\end{array}$ & $\begin{array}{c}2,902.58 * * * \\
(0.000)\end{array}$ & $\begin{array}{c}1489.58 * * * \\
(0.000)\end{array}$ & $\begin{array}{c}31.53 * * * \\
(0.000)\end{array}$ \\
\hline
\end{tabular}

$\dagger, *, * *$, and $* * *$ indicate significance at the $15 \%, 10 \%, 5 \%$ and $1 \%$ levels, respectively 
TABLE 6: Debt Maturity Regression Results (p-values in parentheses)

\begin{tabular}{|c|c|c|c|c|c|c|}
\hline & (1) & (2) & (3) & (4) & (5) & (6) \\
\hline $\begin{array}{l}\text { Dependent } \\
\text { Variable }\end{array}$ & \multicolumn{6}{|c|}{ Long-Term Debt / Total Debt } \\
\hline Estimation & OLS & Robust OLS & Tobit & OLS & Robust OLS & Tobit \\
\hline Constant & $\begin{array}{c}-0.124 * * * \\
(0.000)\end{array}$ & $\begin{array}{c}-0.124 * * * \\
(0.000)\end{array}$ & $\begin{array}{c}-0.651^{* * *} \\
(0.000)\end{array}$ & $\begin{array}{l}0.034^{*} \\
(0.070) \\
\end{array}$ & $\begin{array}{l}0.034^{*} \\
(0.065) \\
\end{array}$ & $\begin{array}{c}-0.278 * * * \\
(0.000)\end{array}$ \\
\hline EffTax & $\begin{array}{c}0.000 \\
(0.602)\end{array}$ & $\begin{array}{c}0.000 \\
(0.607)\end{array}$ & $\begin{array}{c}0.001 \\
(0.502)\end{array}$ & -- & -- & -- \\
\hline Tang & $\begin{array}{c}0.233 * * * \\
(0.000)\end{array}$ & $\begin{array}{c}0.235 * * * \\
(0.000)\end{array}$ & $\begin{array}{c}0.398 * * * \\
(0.000)\end{array}$ & $\begin{array}{c}0.150 * * * \\
(0.000)\end{array}$ & $\begin{array}{c}0.150 * * * \\
(0.000)\end{array}$ & $\begin{array}{c}0.323 * * * \\
(0.000)\end{array}$ \\
\hline ROA & $\begin{array}{l}-0.005 \\
(0.257)\end{array}$ & $\begin{array}{l}-0.005 \\
(0.326)\end{array}$ & $\begin{array}{l}-0.011 \\
(0.214)\end{array}$ & -- & -- & -- \\
\hline LnTA & $\begin{array}{c}0.005 * * * \\
(0.001)\end{array}$ & $\begin{array}{c}0.005 * * * \\
(0.001)\end{array}$ & $\begin{array}{c}0.025^{* * *} * \\
(0.000)\end{array}$ & $\begin{array}{c}0.009 * * * \\
(0.000)\end{array}$ & $\begin{array}{c}0.009 * * * \\
(0.000)\end{array}$ & $\begin{array}{c}0.047 * * * \\
(0.000)\end{array}$ \\
\hline AssetSpec & $\begin{array}{c}0.036 * * * \\
(0.000)\end{array}$ & $\begin{array}{c}0.036 * * * \\
(0.000)\end{array}$ & $\begin{array}{c}0.057^{* * * *} \\
(0.000)\end{array}$ & $\begin{array}{c}0.018 * * * \\
(0.000)\end{array}$ & $\begin{array}{c}0.018^{* * *} \\
(0.000)\end{array}$ & $\begin{array}{c}0.038 * * * \\
(0.000)\end{array}$ \\
\hline LnPCgdp & $\begin{array}{c}0.004 \\
(0.510) \\
\end{array}$ & $\begin{array}{c}0.004 \\
(0.520)\end{array}$ & $\begin{array}{l}-0.004 \\
(0.652)\end{array}$ & $\begin{array}{c}-0.035 * * * \\
(0.000)\end{array}$ & $\begin{array}{c}-0.035^{*} * * \\
(0.000)\end{array}$ & $\begin{array}{c}-0.131 * * * \\
(0.000)\end{array}$ \\
\hline M3/GDP & $\begin{array}{c}0.001 * * * \\
(0.000)\end{array}$ & $\begin{array}{c}0.001 * * * \\
(0.000)\end{array}$ & $\begin{array}{c}0.002 * * * \\
(0.000)\end{array}$ & $\begin{array}{c}0.001 * * * \\
(0.000)\end{array}$ & $\begin{array}{c}0.001 * * * \\
(0.000)\end{array}$ & $\begin{array}{c}0.004 * * * \\
(0.000)\end{array}$ \\
\hline GDP growth & $\begin{array}{c}-0.004 * * * \\
(0.000)\end{array}$ & $\begin{array}{c}-0.004 * * * \\
(0.000)\end{array}$ & $\begin{array}{c}-0.005 * * * \\
(0.000)\end{array}$ & $\begin{array}{c}0.003 * * * \\
(0.000)\end{array}$ & $\begin{array}{c}0.003^{* * *} \\
(0.000)\end{array}$ & $\begin{array}{c}0.011 * * * \\
(0.000)\end{array}$ \\
\hline Term Spread & $\begin{array}{c}-0.002 * * * \\
(0.002)\end{array}$ & $\begin{array}{c}-0.002 * * * \\
(0.000) \\
\end{array}$ & $\begin{array}{c}0.000 \\
(0.897) \\
\end{array}$ & $\begin{array}{l}-0.000 \\
(0.579) \\
\end{array}$ & $\begin{array}{l}-0.000 \\
(0.562) \\
\end{array}$ & $\begin{array}{c}0.004 * * * \\
(0.000)\end{array}$ \\
\hline RuleLaw & $\begin{array}{c}0.003 \\
(0.219) \\
\end{array}$ & $\begin{array}{c}0.003 \\
(0.220) \\
\end{array}$ & $\begin{array}{c}0.027 * * * \\
(0.000) \\
\end{array}$ & $\begin{array}{c}0.022 * * * \\
(0.000)\end{array}$ & $\begin{array}{c}0.022 * * * \\
(0.000)\end{array}$ & $\begin{array}{c}0.073 * * * \\
(0.000)\end{array}$ \\
\hline DeltaEmCred & $\begin{array}{c}0.017 * * * \\
(0.000)\end{array}$ & $\begin{array}{c}0.017 * * * \\
(0.000)\end{array}$ & $\begin{array}{c}0.058 * * * \\
(0.000)\end{array}$ & $\begin{array}{c}0.018 * * * \\
(0.000)\end{array}$ & $\begin{array}{c}0.018^{* * *} \\
(0.000)\end{array}$ & $\begin{array}{c}0.050 * * * \\
(0.000)\end{array}$ \\
\hline Overall $\mathbf{R}^{2}$ & \multicolumn{2}{|c|}{$12.22 \%$} & $17.55 \%$ & \multicolumn{2}{|c|}{$10.46 \%$} & $19.25 \%$ \\
\hline Obs & \multicolumn{3}{|c|}{11,725} & \multicolumn{3}{|c|}{35,853} \\
\hline $\mathbf{R}^{2}$ or Pseudo $\mathbf{R}^{2}$ & $\begin{array}{c}148.23 * * * \\
(0.000)\end{array}$ & $\begin{array}{c}120.52 * * * \\
(0.000)\end{array}$ & $\begin{array}{c}1814.04 * * * \\
(0.000)\end{array}$ & $\begin{array}{c}465.27 * * * \\
(0.000)\end{array}$ & $\begin{array}{c}395.96 * * * \\
(0.000)\end{array}$ & $\begin{array}{c}6469.73 * * * \\
(0.000)\end{array}$ \\
\hline
\end{tabular}

$\dagger, *, * *$, and $* * *$ indicate significance at the $15 \%, 10 \%, 5 \%$ and $1 \%$ levels, respectively 
TABLE 7: Legal Origin Regression Results ( $p$-values in parentheses)

\begin{tabular}{|c|c|c|c|c|c|c|c|c|}
\hline & (1) & (2) & (3) & (4) & (5) & (6) & (7) & (8) \\
\hline $\begin{array}{l}\text { Dependent } \\
\text { Variable }\end{array}$ & \multicolumn{4}{|c|}{$\begin{array}{c}\text { Leverage } \\
(\text { LTD/TA) }\end{array}$} & \multicolumn{4}{|c|}{$\begin{array}{c}\text { Maturity } \\
\text { (LTD/TD) }\end{array}$} \\
\hline Estimation & Tobit & GLS Tobit & Tobit & GLS Tobit & Tobit & GLS Tobit & Tobit & GLS Tobit \\
\hline Constant & $\begin{array}{c}-0.308 * * * \\
(0.000)\end{array}$ & $\begin{array}{c}-0.483 * * * \\
(0.000)\end{array}$ & $\begin{array}{c}0.257 * * * \\
(0.000) \\
\end{array}$ & $\begin{array}{c}-0.135 * * * \\
(0.000)\end{array}$ & $\begin{array}{c}-0.278 * * * \\
(0.000)\end{array}$ & $\begin{array}{c}-0.559 * * * \\
(0.000)\end{array}$ & $\begin{array}{c}0.549 * * * \\
(0.000) \\
\end{array}$ & $\begin{array}{c}0.191 * * * \\
(0.000) \\
\end{array}$ \\
\hline Efftax & $\begin{array}{c}0.000 \\
(0.945) \\
\end{array}$ & $\begin{array}{l}-0.000 \\
(0.899) \\
\end{array}$ & -- & -- & $\begin{array}{c}0.001 \\
(0.413) \\
\end{array}$ & $\begin{array}{c}0.000 \\
(0.661) \\
\end{array}$ & -- & -- \\
\hline Tang & $\begin{array}{c}0.203 * * * \\
(0.000) \\
\end{array}$ & $\begin{array}{c}0.182 * * * \\
(0.000) \\
\end{array}$ & $\begin{array}{c}0.162 * * * \\
(0.000) \\
\end{array}$ & $\begin{array}{c}0.152 * * * \\
(0.000) \\
\end{array}$ & $\begin{array}{c}0.400 * * * \\
(0.000) \\
\end{array}$ & $\begin{array}{c}0.355 * * * \\
(0.000)\end{array}$ & $\begin{array}{c}0.311^{* * * *} \\
(0.000) \\
\end{array}$ & $\begin{array}{c}0.268 * * * \\
(0.000) \\
\end{array}$ \\
\hline ROA & $\begin{array}{c}-0.028 * * * \\
(0.000)\end{array}$ & $\begin{array}{c}-0.031 * * * \\
(0.000)\end{array}$ & -- & -- & $\begin{array}{c}-0.008 \\
(0.348) \\
\end{array}$ & $\begin{array}{c}-0.013 * * * \\
(0.000)\end{array}$ & -- & -- \\
\hline LnTA & $\begin{array}{c}0.025 * * * \\
(0.000)\end{array}$ & $\begin{array}{c}0.030 * * * \\
(0.000)\end{array}$ & $\begin{array}{c}0.032 * * * \\
(0.000)\end{array}$ & $\begin{array}{c}0.033 * * * \\
(0.000)\end{array}$ & $\begin{array}{c}0.020 * * * \\
(0.000)\end{array}$ & $\begin{array}{c}0.024 * * * \\
(0.000)\end{array}$ & $\begin{array}{c}0.042 * * * \\
(0.000)\end{array}$ & $\begin{array}{c}0.013 * * * \\
(0.000)\end{array}$ \\
\hline AssetSpec & $\begin{array}{c}0.035 * * * \\
(0.000) \\
\end{array}$ & $\begin{array}{c}0.031 * * * \\
(0.000) \\
\end{array}$ & $\begin{array}{c}0.029 * * * \\
(0.000) \\
\end{array}$ & $\begin{array}{c}0.023 * * * \\
(0.000) \\
\end{array}$ & $\begin{array}{c}0.058 * * * \\
(0.000) \\
\end{array}$ & $\begin{array}{c}0.058 * * * \\
(0.000) \\
\end{array}$ & $\begin{array}{c}0.047 * * * \\
(0.000) \\
\end{array}$ & $\begin{array}{c}0.056^{* * *} * \\
(0.000) \\
\end{array}$ \\
\hline LnPCgdp & $\begin{array}{c}-0.023 * * * \\
(0.000)\end{array}$ & $\begin{array}{c}0.000 \\
(0.897)\end{array}$ & $\begin{array}{c}-0.081 * * * \\
(0.000)\end{array}$ & $\begin{array}{c}-0.030 * * * \\
(0.000)\end{array}$ & $\begin{array}{l}-0.012 \\
(0.251)\end{array}$ & $\begin{array}{c}0.025 * * * \\
(0.000)\end{array}$ & $\begin{array}{c}-0.146^{* * *} \\
(0.000)\end{array}$ & $\begin{array}{c}-0.064 * * * \\
(0.000)\end{array}$ \\
\hline M3/GDP & $\begin{array}{c}0.001 * * * \\
(0.000)\end{array}$ & $\begin{array}{c}0.001 * * * \\
(0.003)\end{array}$ & $\begin{array}{c}0.001 * * * \\
(0.000)\end{array}$ & $\begin{array}{l}-0.000 \\
(0.310)\end{array}$ & $\begin{array}{c}0.001 * * \\
(0.037)\end{array}$ & $\begin{array}{c}0.000 \\
(0.826)\end{array}$ & $\begin{array}{c}0.002 * * * \\
(0.000)\end{array}$ & $\begin{array}{c}0.000 \\
(0.346)\end{array}$ \\
\hline GDP growth & $\begin{array}{c}0.001 \\
(0.311) \\
\end{array}$ & $\begin{array}{c}0.002 * * * \\
(0.001)\end{array}$ & $\begin{array}{c}0.002 * * * \\
(0.000) \\
\end{array}$ & $\begin{array}{c}0.003 * * * \\
(0.000) \\
\end{array}$ & $\begin{array}{c}-0.010 * * * \\
(0.000)\end{array}$ & $\begin{array}{c}-0.007 * * * \\
(0.000)\end{array}$ & $\begin{array}{c}0.006^{* * *} \\
(0.000)\end{array}$ & $\begin{array}{c}0.005 * * * \\
(0.000) \\
\end{array}$ \\
\hline Term Spread & -- & -- & -- & -- & $\begin{array}{c}-0.005 * * * \\
(0.000) \\
\end{array}$ & $\begin{array}{c}-0.006 * * * \\
(0.000)\end{array}$ & $\begin{array}{c}0.001 \\
(0.185) \\
\end{array}$ & $\begin{array}{c}0.000 \\
(0.434) \\
\end{array}$ \\
\hline RuleLaw & $\begin{array}{c}0.017 * * * \\
(0.000) \\
\end{array}$ & $\begin{array}{c}0.014 * * * \\
(0.000) \\
\end{array}$ & $\begin{array}{c}0.006 * * * \\
(0.003) \\
\end{array}$ & $\begin{array}{c}0.007 * * * \\
(0.000) \\
\end{array}$ & $\begin{array}{l}0.010 * \\
(0.053) \\
\end{array}$ & $\begin{array}{c}0.006 \\
(0.237) \\
\end{array}$ & $\begin{array}{c}0.011 * * * \\
(0.001)\end{array}$ & $\begin{array}{c}0.013 * * * \\
(0.001)\end{array}$ \\
\hline DeltaEmCred & $\begin{array}{c}0.026 * * * \\
(0.000) \\
\end{array}$ & $\begin{array}{c}0.020 * * * \\
(0.000)\end{array}$ & $\begin{array}{c}0.014 * * * \\
(0.000) \\
\end{array}$ & $\begin{array}{c}-0.003 \\
(0.275) \\
\end{array}$ & $\begin{array}{c}0.043 \\
(0.000) \\
\end{array}$ & $\begin{array}{c}0.031 * * * \\
(0.000)\end{array}$ & $\begin{array}{c}0.027 * * * \\
(0.000) \\
\end{array}$ & $\begin{array}{l}-0.003 \\
(0.212) \\
\end{array}$ \\
\hline French Origin & $\begin{array}{c}-0.069 * * * \\
(0.000)\end{array}$ & $\begin{array}{c}-0.050 * * * \\
(0.000)\end{array}$ & $\begin{array}{c}-0.185^{* * *} * \\
(0.000)\end{array}$ & $\begin{array}{c}-0.131 * * * \\
(0.000)\end{array}$ & $\begin{array}{c}-0.122 * * * \\
(0.000)\end{array}$ & $\begin{array}{c}-0.086 * * * \\
(0.000)\end{array}$ & $\begin{array}{c}-0.310^{* * *} \\
(0.000)\end{array}$ & $\begin{array}{c}-0.262 * * * \\
(0.000)\end{array}$ \\
\hline Eurasian Origin & $\begin{array}{c}-0.027 * * * \\
(0.000)\end{array}$ & $\begin{array}{l}-0.015 \\
(0.449) \\
\end{array}$ & $\begin{array}{c}-0.202 * * * \\
(0.000)\end{array}$ & $\begin{array}{c}-0.148 * * * \\
(0.000)\end{array}$ & $\begin{array}{c}0.006 \\
(0.875) \\
\end{array}$ & $\begin{array}{l}0.066 * \\
(0.056) \\
\end{array}$ & $\begin{array}{c}-0.314^{* * *} \\
(0.000) \\
\end{array}$ & $\begin{array}{c}-0.253 * * * \\
(0.000)\end{array}$ \\
\hline${\text { Overall } \mathbf{R}^{2}}^{2}$ & \multicolumn{2}{|c|}{$31.42 \%$} & \multicolumn{2}{|c|}{$32.91 \%$} & \multicolumn{2}{|c|}{$18.49 \%$} & \multicolumn{2}{|c|}{$21.60 \%$} \\
\hline Obs & \multicolumn{2}{|c|}{16,846} & \multicolumn{2}{|c|}{44,286} & \multicolumn{2}{|c|}{11,725} & \multicolumn{2}{|c|}{35,853} \\
\hline Firms & \multicolumn{2}{|c|}{6,932} & \multicolumn{2}{|c|}{15,617} & \multicolumn{2}{|c|}{5,263} & \multicolumn{2}{|c|}{13,617} \\
\hline LR or Wald Chi ${ }^{2}$ & $\begin{array}{c}2954.1 * * * \\
(0.000)\end{array}$ & $\begin{array}{c}1492.6^{* * *} * \\
(0.000)\end{array}$ & $\begin{array}{c}8544.0^{* * *} \\
(0.000)\end{array}$ & $\begin{array}{c}4159.3 * * * \\
(0.000)\end{array}$ & $\begin{array}{c}1911.9^{* * *} \\
(0.000)\end{array}$ & $\begin{array}{c}1012.3 * * * \\
(0.000)\end{array}$ & $\begin{array}{c}7257.5 * * * \\
(0.000)\end{array}$ & $\begin{array}{c}2985.2 * * * \\
(0.000)\end{array}$ \\
\hline
\end{tabular}

$\dagger, *, * *$, and $* * *$ indicate significance at the $15 \%, 10 \%, 5 \%$ and $1 \%$ levels, respectively 